Mapping the Contours of Contemporary Financial Services Regulation

Julia Black 


\title{
Mapping the Contours of Contemporary \\ Financial Services Regulation
}

\author{
Julia Black
}

\section{Contents}

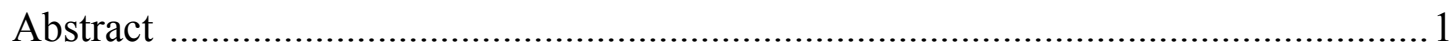

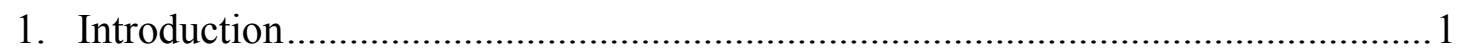

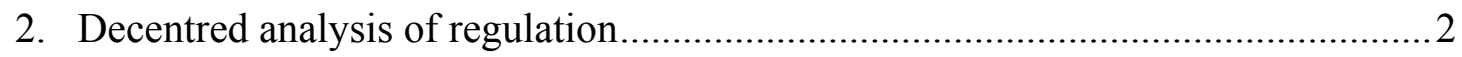

3. The regulatory 'toolkit' and its deployment ..................................................... 3

4. From a tools-based to an enrolment analysis ................................................... 9

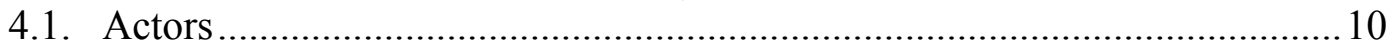

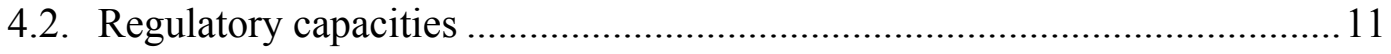

4.3. Regulatory resources, capacities and functions: some examples ..................11

4.4. Responding to changes in regulatory capacity ........................................ 17

5. Using enrolment analysis to 'map' financial services regulation ......................... 19

6. Using enrolment analysis to assess the regulatory system.................................22

7. Implications of an enrolment analysis for the FSA's risk assessment process......24

8. Implications of an enrolment analysis for discussions of accountability ..............25

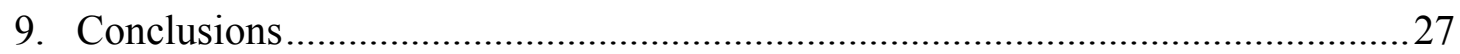

Appendix 1: Differential regulatory capacities: preliminary assessment of capacities

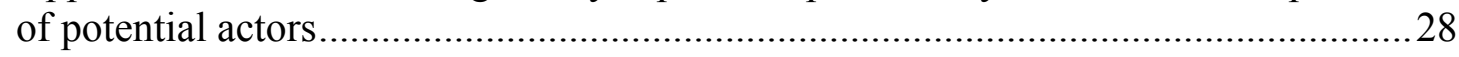


The support of the Economic and Social Research Council (ESRC) is gratefully acknowledged. The work was part of the programme of the ESRC Centre for Analysis of Risk and Regulation.

Published by the Centre for Analysis of Risk and Regulation at the London School of Economics and Political Science

Houghton Street

London WC2A 2AE

(C) London School of Economics and Political Science, 2003

ISBN 0753016532

All rights reserved.

No part of this publication may be reproduced, stored in a retrieval system, or transmitted, in any form or by any means, without the prior permission in writing of the publisher, nor be otherwise circulated in any form of binding or cover other than that in which it is published and without a similar condition including this condition being imposed on the subsequent purchaser.

Printed and bound by Printflow, October 2003. 


\title{
Mapping the Contours of Contemporary Financial Services Regulation
}

\author{
Julia Black*
}

\begin{abstract}
The article draws on decentred analyses of regulation, which emphasise the fragmentation and hybridisation of regulatory systems, to analyse contemporary financial services regulation, principally in the UK. The analysis focuses on actors, their regulatory capacities, the regulatory functions which they do or could perform, their interrelationships, and the ways in which they are or could be enrolled within the regulatory system. The article contrasts such an analysis with the more familiar 'toolkit' analysis, and argues that the enrolment analysis provides a mapping device which facilitates a more nuanced analysis of the nature of regulatory hybridity and fragmentation, and facilitates debates on the development of the regulatory system. It also provides a critical frame in which to assess the likely effectiveness, the adherence to normative values, and the accountability of the regulatory system as a whole.
\end{abstract}

\section{Introduction}

Given the extensive institutional consolidation which has occurred in financial services regulation since 1997, it would appear on the face of it that the regulatory system is now highly centralised. Moreover, there has been a concerted move away from the different forms of selfregulation that existed beforehand. Given such consolidation and the increased presence of statutory underpinning, it seems counter-intuitive to argue that the regulatory system, even at a national level, is in fact highly fragmented and hybrid, and provides an excellent example of decentred regulation. That is in part, however, exactly what this article does argue.

Moreover, it suggests that in order to analyse the nature of contemporary financial services regulation and indeed in order to debate how it should be improved, a different perspective on regulatory systems is needed. The article draws on decentred analyses of regulation to suggest that analysing many contemporary regulatory systems requires the dominant focus on regulatory tools to be supplemented, if not supplanted, by a focus on actual or potential regulatory actors, their regulatory capacities, and how they are or might be 'enrolled' or incorporated into the regulatory process. The article applies such an analysis to the current system of financial services regulation, principally at the national level. It is not the aim to provide a comprehensive map of the regulation, and certainly not a description of its rules.

\footnotetext{
Reader in Law, London School of Economics; Research Member, ESRC Centre for Analysis of Risk and Regulation, London School of Economics. This is an updated version of an article first published in 2002, under the same title, in Journal of Corporate Law Studies, 2 (2): 253-287. The article was researched and written whilst I held a British Academy/Leverhulme Trust Senior Research Fellowship, the support of which is gratefully acknowledged, as is that of the ESRC.
} 
Rather the article aims to contribute to a better understanding of the nature of the financial services regulatory system and to the development and improvement both of the system and its accountability.

Section 2 outlines the key elements of a decentred analysis of regulation. Section 3 outlines the standard set of regulatory 'tools' and illustrates how they are currently deployed. Section 4 outlines the central elements of an enrolment analysis and argues why, given the decentred analysis of regulation, it might be profitable to supplement a tools-based analysis with an enrolment perspective, one that focuses on actors, their regulatory capacities, the different regulatory functions they could or do perform, and the various ways in which they are, or might be, enrolled within the regulatory system. Section 5 then uses the analysis to 'map' certain aspects of the regulatory system, providing an alternative to a tools-based analysis, and illustrates how enrolment decisions might have to change in response to changes in regulatory capacity. Section 6 argues that an enrolment analysis provides both a mapping device, and perhaps more importantly a critical frame in which to assess whether the particular nature of the fragmentation and hybridisation manifested by the regulatory system is appropriate: whether the 'right' actors are charged with the 'right' task, where 'right' is judged both in pragmatic terms (their effectiveness at achieving regulatory aims), and in normative terms (their legitimacy in performing their particular role). Finally, sections 7 and 8 outline some of the implications of the analysis for the Financial Services Authority's (FSA) own risk-based approach to regulation and for debates on the accountability of the system as a whole.

\section{Decentred analysis of regulation}

The decentred (or 'multi-centred') analysis of regulation emphasises the complexity of social problems, the complexity of the nature of interactions between and within state and society, the fragmentation of knowledge, and the fragmentation of power and control. It perceives the state as being both regulated and a regulator, and does not assume it to have a monopoly on regulation: there is 'regulation in many rooms'. It emphasises fragmentation both of the state and of society, and hybridity - the interaction of state and society in producing regulation.

There are a number of implications of the analysis for understandings of regulation. ${ }^{1}$ One of these, it is suggested, is that a slightly different analytical frame needs to be adopted in order to facilitate analysis of any regulatory system, and indeed to begin to debate issues of its effectiveness and accountability. That frame is not one of a regulatory toolkit, but principally one of enrolment. In other words, in order to both describe and prescribe for the regulatory system, a focus needs to be placed on the actors involved (extending well beyond the regulated firm/industry and the regulator), on their regulatory capacities, and on how they are and should be enrolled within a regulatory system. The elements of an enrolment analysis are set out

\footnotetext{
1 Black, J. (2001) 'Decentring Regulation: Understanding the Role of Regulation and Self Regulation in a 'PostRegulatory' World', Current Legal Problems, 54: 103-146; Black, J. (2002) Critical Reflections on Regulation, CARR Discussion Paper no. 4, London, CARR, LSE (also in Australian Journal of Legal Philosophy, 27 (1): 1-36, and Kingsford Smith, D. (2002) 'What is Regulation? A Reply to Julia Black's 'Critical Reflections on Regulation', Australian Journal of Legal Philosophy, 27 (1): 37-46; Hancher, L. and Moran, M. (1989) 'Organizing Regulatory Space' in L. Hancher and M. Moran, (1989) Capitalism, Culture and Regulation. Oxford, OUP; Scott, C. (2001) 'Analysing Regulatory Space: Fragmented Resources and Institutional Design', Public Law, 2001: 283305.
} 
below. However, in order to provide a framework against which to contrast the approach it is perhaps useful to consider how the more familiar 'toolkit' analysis applies to the UK financial services regulatory system.

\section{The regulatory 'toolkit' and its deployment}

The FSA has already set out the new regulatory approach it proposes to adopt: one that is riskbased, and which seeks to draw widely on the regulatory 'toolkit'. ${ }^{2}$ The former is a relatively innovative approach to regulation and deserves separate consideration; the latter strategy is one which has been much explored in the literature at least. Should it choose to look, the FSA will find that there is no shortage of academic and governmental publications that seek to provide models on what those tools might be, and how they might be used. ${ }^{3}$

Most commonly, regulatory systems are analysed by the tools that are deployed (are they legal, economic, social, etc), and by who is deploying them (is it government, the market, the community). ${ }^{4}$ It is important to stress that any of the regulatory tools may be used by the state, the market, the community, associations, networks, organisations or individual actors (including firms) (with the obvious exception within a liberal democracy that the use of force and imprisonment are confined to the state), and that complex sets of relationships between these actors may exist. All too often debates about the appropriate structure of regulation, particularly in the financial services context, take the black or white, state or self-regulatory form. The reality is that these are but two examples of a far wider range of possible configuration of relationships and roles.

If we use a toolkit analysis to describe UK financial services regulation, it quickly becomes clear that the regulation provides numerous examples of all the main types of regulatory tools: written norms (legal and non-legal) and accompanying sanctions, economic- or market-based instruments, social norms and accompanying sanctions, technologies and processes. Firstly, written norms, both legal and non-legal, are used extensively. At a simple level of analysis, the 'command and control' (CAC) model, stripped of the pejorative connotations that usually accompany it, is the predominant form of regulation for an increasingly wide range of financial services activities: legal rules backed by civil, criminal and administrative sanctions monitored and enforced by a government-empowered body, although to dismiss all of financial services

2 FSA (2000) A New Regulator for the New Millennium (December 2000); (2000) Building the New Regulator: Progress Report 1; (2002) Building the New Regulator: Progress Report 2 (February 2002).

3 Eg, Sparrow, K. (2000) The Regulatory Craft: Controlling Risks, Solving Problems and Managing Compliance. Washington DC, Brookings Institute; Gunningham, N. and Grabovsky, P. (1997) Smart Regulation. Oxford, OUP; OECD (1997) The OECD Report on Regulatory Reform: Synthesis. Paris, OECD; Australian Productivity Commission, Office of Regulatory Review (1999) A Guide to Regulation (2 ${ }^{\text {nd }}$ ed). Canberra, Office of Regulatory Review; Treasury Board of Canada (1994) Regulatory Affairs Guide, Assessing Regulatory Alternatives. Ontario, Treasury Board of Canada; The Better Regulation Taskforce (2000) Alternatives to State Regulation. London, The Better Regulation Taskforce (July 2000).

4 See, for example, Baldwin, R. and Cave, M. (1999) Understanding Regulation. Oxford, OUP, Ch. 4; Hood, C. (1983) Tools of Government, London, Macmillan; Daintith, T. (1994) 'Techniques of Government' in J. Jowell and D. Oliver (1994) The Changing Constitution ( $3^{\text {rd }}$ ed). Oxford, OUP; Gunningham and Grabovsky, supra n. 3, Ch. 2. 
regulation into a ' $\mathrm{CAC}$ ' box, even one more sophisticated in interior design than most, is too crude.

Legal norms are also used to create or alter private rights, for example the private right of action for breach of the rules conferred in the Financial Services and Markets Act 2000 (FSMA) is designed with the hope that it will provide an incentive to firms to comply with the rules, though evidence of the effectiveness of its predecessor is inconclusive (it certainly was not well used). ${ }^{5}$ More likely to be successful is the conferral on regulators of the right to enforce rights granted to individuals, such as the rights given to the FSA to bring actions under the Unfair Terms in Consumer Contracts Regulations. ${ }^{6}$ The proposed requirement for banks to issue subordinated debt is another example in which regulation seeks to create or alter private rights and liabilities in order to achieve its aims. ${ }^{7}$ Under this proposal banks would be required to issue a particular class of debt instrument; regulators would then use the price of the debt as a signal of the market's assessment of the financial soundness of the bank. In other words, they would seek to gain information from market actors as to a bank's financial position, but do so indirectly, through the price mechanism. Market actors can also use private law powers to create more limited private rights, for example to demand collateral, or require certain disclosures, assuming they have the market power to do so (and the law will support their efforts).

Non-legal written norms are also a distinctive feature of financial services regulation. The FSA has the power to issue guidance which is not legally binding and to issue rules which have evidential status only, ${ }^{8}$ and it has used both extensively. Industry codes also abound and there remains, for the moment, a strong element of non-legal, industry-led regulation in financial services, though this has clearly diminished in the last 15 years or so. Banks' relationships with their customers are governed by the Banking Code ${ }^{9}$ and Business Banking Code ${ }^{10}$ issued by the British Banking Association, monitored and enforced by the Banking Code Standards Board. Whilst the FSA is to take over the regulation of mortgage advice in 2004, until that time it remains governed by the Mortgage Code issued by the Council of Mortgage Lenders ${ }^{11}$ and monitored and enforced by the Mortgage Code Compliance Board. Organised exchanges are still responsible for their own regulation (although the responsibility for maintaining the official list and admission of securities to listing on the Stock Exchange has been transferred to the

5 Financial Services Act 1986, s. 62A; Financial Services and Markets Act 2000 (FSMA), s. 150.

6 UTCCR 1999, reg. 12; FSA Handbook ENF 6.9 and 6.10.

7 For discussion, see US Shadow Financial Regulatory Committee, A Proposal for Reforming Bank Capital Regulation (Statement No 160, 2 March 2000) available at www.aei.org/shdw/shdw160.htm; Dhumale, R. (2001) 'Incentive vs Rule-Based Financial Regulation: A Role for Market Discipline' in E. Ferran and C. Goodhart (eds), Regulating Financial Services Markets in the $21^{\text {st }}$ Century. Oxford, Hart Publishing.

8 FSMA s. 157 (guidance) and s. 149 (evidential provisions).

$9 \quad$ First issued in 1991.

10 Issued in March 2002.

11 First issued in 1997, revised in March 2002 taking into account recommendations of the Banking Services Consumer Codes Review Group's report, Cracking the Codes for Consumers (chair: DeAnne Julius), London, HM Treasury, 2001). 
FSA). ${ }^{12}$ The regulation of takeovers remains predominantly the preserve of the Takeover Panel, one of the most well-known and arguably successful examples of self-regulation in the UK.

Secondly, economic and market instruments are used by both governmental and nongovernmental actors. Government-imposed capital adequacy requirements are prime examples of economic-based regulation, requiring firms to internalise the cost of their risk-taking by imposing a tax on those activities. Examples of non-governmental, market-based regulation are the activities of credit and fund management ratings agencies.

Written norms and market instruments are often used in conjunction. For example, the subordinated debt proposals, if implemented, would be an example of the deliberate creation of a market by the government in order to then utilise that market to achieve its own ends; the creation of the market in personal pensions in the 1980s provides an alternative example. Another example is mandatory disclosure requirements. Mandatory disclosure is a central plank of financial services regulation at the international and national level, and is intended to facilitate and stimulate market-based regulation, facilitating and enhancing the rational choices that market actors are assumed to be making.

Thirdly, social norms and sanctions are also used by government and non-governmental actors. Legal rules can alter social norms: indeed it is the ultimate goal that they should. ${ }^{13}$ Government (again in the form of the FSA) also attempts to alter social norms through instruments of education and information that take a 'softer' form. These include, for example, giving guidance, through face-to-face discussions, eg, in the course of monitoring or enforcement visits or through seminars or conferences, and education. Education in the past has been something of a Cinderella technique of financial regulation, but the FSA's statutory objective of improving consumer understanding is ensuring that education of consumers is receiving far more attention, ${ }^{14}$ and the repeated waves of mis-selling scandals have had some effect in raising the education requirements for financial services operatives. The use of peer pressure to ensure that firms act in accordance with certain standards of behaviour can also be a powerful social tool. Industry-based initiatives such as the Association of British Insurers (ABI)'s system for accreditation of disclosure particulars for with-profits policies are based on the intention that peer pressure will cause firms to comply with the code or face ostracisation (and loss of market share). However, the clearest example of the deployment of social norms and sanctions is probably the practice of 'cold shouldering' those who refuse to comply with the Takeover Panel's rulings, ${ }^{15}$ and the 'naming and shaming' aspect of enforcement processes. For example, the potential harm to a firm's reputation from the publication of a finding that it

12 Official Listing of Securities (Change of Competent Authority) Regulations 2000 (SI 2000/968); FSMA Part VI.

13 Eg, Selznick, P. (1992) The Moral Commonwealth. Berkeley, University of California Press, p.235.

14 See publications on the FSA's website: www.fsa.gov.uk/consumers

15 Though this has now been partly codified by the FSA: FSA (April 2001) CP87 Endorsement of the City Code on Takeovers and Mergers and the Rules Governing Substantial Acquisition of Shares. London, FSA; FSA Handbook MAR 4.3.1-4.3.4. 
has participated in money laundering has been cited by firms as a key incentive to compliance with the money laundering rules. ${ }^{16}$

Written norms, economic- and market-based instruments and social norms are all familiar categories of regulatory tools, together with their accompanying sanctions. Less familiar to the standard categorisations are those of technologies and processes. The fourth category of 'technologies' is inspired by Rose and Miller's ${ }^{17}$ writings on governance, but in order to identify the role it plays in regulation it needs to be more finely graded so as to distinguish it from the other types of instruments that Rose and Miller would otherwise include under the term. So by 'technologies' it is meant here, the specialist understandings of and ability to employ, manipulate, calculate, measure or alter the physical, economic or human environment and the products of that understanding. The role of 'technologies' in this sense in regulating is not yet part of the mainstream regulatory literature, but has been noted in diverse writings on, for example, audit, ${ }^{18}$ risk, $^{19}$ and sociologies of control. ${ }^{20}$

The place of 'technologies' in regulation is thus that they are the understandings of the world on which the design of both the problem that regulation seeks to address and the solution to that problem are built, and it is suggested that they form an important part of the strategies that are used in attempts to modify behaviour. At their simplest they may be the design of the physical environment or its virtual equivalent. ${ }^{21}$ At a more complex level, examples in financial services regulation include the extensive reliance on different forms of audit: both traditional accounting audit, but also the development and reliance on compliance audits, both by regulator and regulated and the move to modes of 'meta-regulation' (the audit of audits), ${ }^{22}$ the development of and reliance on risk modelling, first of market and more recently of credit and

16 FSA (2001), The Money Laundering Theme: Tackling Our New Responsibilities, para A.10. (July 2001)

17 See in particular N. Rose and P. Miller (1992) 'Political Power Beyond the State: Problematics of Government' British Journal of Sociology 43(2): 172-205.

18 Power, M. (1998) The Audit Society: Rituals of Verification. Oxford, OUP.

19 Bernstein, P.L. (1996) Against the Gods: The Remarkable Story of Risk. New York, John Wiley \& Sons; Hacking, I. (1990) The Taming of Chance. Cambridge, CUP.

20 Law, J. (1986) 'On the Methods of Long-Distance Control: Vessels, Navigation and the Portuguese Route to India' and Callon, M. (1986) 'Domestication of the Scallops and the Fishermen of St Brieuc Bay: Some Elements of the Sociology of Translation', both in J. Law (ed) (1986) Power, Action, Belief: A New Sociology of Knowledge? London, Routledge \& Kegan Paul; Law, J. and Hussard, J. (eds) (1999) Actor-Network Theory and After. Oxford, Blackwell's for Sociological Review; Rose, N. and Miller, P. (1992) 'Political Power Beyond the State: Problematics of Government', British Journal of Sociology, 43 (2): 172-205; Rose, N. (1999) Powers of Freedom. Cambridge, Cambridge University Press, pp: 52-55.

21 On the importance of the design of the physical environment see, eg, Shearing, C. and Stenning, P. (1984) 'From the Panopticon to Disney World: The Development of Discipline' in A. Doob and E. Greenspan (eds) (1989) Perspectives in Criminal Law. Aurora, Canada Law Book Co.; Sparrow supra n 3, 124-9; on the design of the virtual environment see Lessig, L. (1999) Code and Other Laws of Cyberspace. New York, Basic Books.

22 Braithwaite, J. (2000) 'The New Regulatory State and the Transformation of Criminology', British Journal of Criminology, 40: 222-238; Parker, C. (2000) 'Reinventing Regulation within the Corporation: ComplianceOriented Regulatory Innovation', Administration and Society, 32 (5): 529-565. 
operational risk, ${ }^{23}$ and even the development and reliance by firms on 'suitability' templates for investments or 'affordability' calculators for mortgages to ensure compliance with regulation.

The fifth category is processes: the design of organisational and decision-making processes in such a way as to try to ensure that appropriate outcomes are reached, bearing in mind that the outcome desired simply might be that a particular process was followed, eg, that certain actors or groups participated. ${ }^{24}$ In other words the process might be, in terms of the attainment of policy objectives, the goal itself, rather than the means for achieving that goal. In the broader financial services context, the code on corporate governance provides an example of a decision process as a goal: what is important, at least for compliance, is that certain decisions are taken by certain actors with certain powers (audit committees, remuneration committees), not what decision they reach. Whilst it is hoped that appropriate decisions will be reached there is no direct regulation of them. In contrast, the guidance on the design of internal controls provides an example of using processes more explicitly as an instrument to reach a desired end: processes have to be put in place, but the regulation also specifies the type of outcome that should result and imposes liability in certain circumstances if it is not. Process-based regulation may also take the form trying to balance opposing forces through the design of processes. Examples in the regulatory literature are Dunsire's model of collibration, ${ }^{25}$ Braithwaite's model of tripartism, ${ }^{26}$ and Braithwaite's model of restorative justice. ${ }^{27}$ Collibration refers to the balancing of forces to attain an equilibrium: as developed by Dunsire it is to posit against one another groups with opposing sets of interests or objectives within a regulatory system and to act so as to equalise so far as possible the power relations between them, so that the regulation that results reflects the balance between them (note, not a compromise or consensus between them: this is not a discursive model of regulation). Tripartism seeks basically the same result, though through a less complex theoretical route: it is that performance of critical regulatory functions, including enforcement and imposition of sanctions, should be conducted by representatives of industry, government and consumers. Examples of collibration and partial examples of tripartism in the financial services context are the requirements for the composition of the Board of the FSA and the requirement that it has to have regard to both the practitioner and consumer panels, which hold equal positions, at least in formal terms, in the regulatory process. ${ }^{28}$

\footnotetext{
23 Basel Committee on Banking Supervision (BCBS) (2001) Consultative Document: Overview of the New Basel Capital Accord. Basel, BIS; (2001) Consultative Document: The Internal Ratings Based Approach. Basel, BIS; (2001) Consultative Document: Operational Risk. Basel, BIS.

${ }^{24}$ This often takes the form of a plea for some form of deliberative or participative process: for discussion and critique see Black, J. (2000) 'Proceduralising Regulation: Part I', Oxford Journal of Legal Studies, 20 (4): 597-614 and (2001) 'Proceduralising Regulation: Part II', Oxford Journal of Legal Studies, 21 (1): 33-58.

25 Dunsire, A. (1996) 'Tipping the Balance: Autopoiesis and Governance', Administration and Society, 28 (3): 299-334.

26 Ayres, I. and Braithwaite, J. (1992) Responsive Regulation: Transcending the Regulation Debate. Oxford, OUP.

27 Braithwaite, J. (2001) Restorative Justice and Responsive Regulation. Oxford, OUP.

28 FSMA ss 8-12.
} 
Finally, the point has to be made that, as is frequently noted, effective regulation often involves a combination of different types of tools in which government and industry/markets act either together or sequentially over time to alter behaviour in the way that it is hoped will achieve the desired outcome. $^{29}$ The move to such hybrid and indirect strategies of regulation is part of what may be termed the 'new generation' of regulatory theories, in which the regulatory toolkit is considerably expanded and the designs more nuanced than in the classic expositions of regulatory alternatives characteristic of earlier regulatory thinking. ${ }^{30}$

Much of financial services regulation is in reality hybrid, both in practice and in design. The Banking Code may be issued and monitored by an association of the banking industry, but it now operates in the knowledge that the FSA has reserve powers to take over should it prove to be failing. ${ }^{31}$ The Mortgage Code has a clear expiry date. Endorsement of the Takeover Panel's rules $^{32}$ enables the Takeover Panel to utilise the FSA's statutory enforcement and investigation powers should it so wish. The organised exchanges are subject to recognition by the FSA subject to certain requirements as to their regulation, and the FSA may now issue directions to them to alter their rules or practices should it deem that those requirements are failing to be met. $^{33}$ Their ability to continue to couple their regulatory role with their commercial one is in any event being called into doubt as alternative trading platforms develop. ${ }^{34}$ Collective industry self-regulation also operates in parallel with the statutory regime, with some industry associations issuing their own codes of practice that elaborate on or extend beyond regulatory requirements: the ABI's code on disclosures for with-profits policies noted above, and that of the Association of Investment Trust Companies (AITC) on disclosure for split trusts ${ }^{35}$ provide good examples. Moving from the collective level of industry action to the level of individual firms, financial services regulation is paying increasing attention to internal systems and controls. The amendment to the Capital Accord in 1996 to allow banks to use their own risk models to set part of their capital charge relating to market risk ${ }^{36}$ is a textbook example of enforced self-regulation, and one which it is proposed to extend at the international and, therefore, national level. ${ }^{37}$ The internal management principles and the Code of Conduct for

29 Gunningham and Grabovsky, supra n. 3; Baldwin and Cave, supra n. 4.

30 Eg, Breyer, S. (1982) Regulation and its Reform, Cambridge, MA, Harvard University Press.

31 FSMA Sched. 2 para 23; FSMA (Regulated Activities) Order 2001 (SI 2001/544) as amended.

32 FSMA s. 143.

33 FSMA s. 296.

34 FSA (2000) The FSA's Approach to the Regulation of Market Infrastructure. Discussion Paper 2 (January 2000) and see further below.

35 AITC (2000) Guide to Good Practice for the Report and Accounts of Investment Trust Companies. (January 2000).

36 BCBS (1996) Amendment to the Capital Accord to Incorporate Market Risk. Basel, BCBS (January 1996) as amended.

37 BCBS (2001) The New Capital Accord. Basel, BIS. (January 2001); BCBS (2003) The New Basle Capital Accord, Third Consultative Paper. 
Approved Persons ${ }^{38}$ also illustrate that 'meta-regulation', the regulation of firm's own internal regulation, is becoming an important template in regulatory design.

\section{From a tools-based to an enrolment analysis}

Attempts to capture the nature and form of this hybridity have thus far resulted in increasingly nuanced typologies of self-regulation. ${ }^{39}$ Some focus on the relationship of the system with government. For example, mandated self-regulation, in which a collective group is required or designated by the government to formulate and enforce norms within a broad framework set by government (eg, the old structure of self-regulatory organisations); sanctioned self-regulation in which the collective group formulates rules which are then approved by government; coerced self-regulation, in which the industry formulates and imposes regulation but only in response to the threat of statutory regulation. In addition, government may have taken backstop statutory powers to impose such regulation: sometimes also described as 'regulation in the shadow of the law' or 'co-regulation'. These are counterposed against voluntary self-regulation, where there is no government involvement, direct or indirect, in promoting or mandating self-regulation - a rare phenomenon.

Governments and firms or associations are not the only potential actors in systems of regulation. Others may play a key role, such as auditors, technical committees, community groups, non-governmental organisations (NGOs), as explored below. This involvement may take various forms, which themselves could be categorised as ever-more exotic forms of 'self'regulation. For example, 'stakeholder' self-regulation, in which there is involvement by consumer or community representatives on rule-making or disciplinary panels, or agreements with local communities. Alternatively, or in addition, there could be 'verified' self-regulation, in which third parties are responsible for monitoring compliance (auditors, NGOs, others), or 'accredited' self-regulation, in which rules and compliance are accredited by another nongovernmental body (eg, standards council or other technical committee). ${ }^{40}$

Many of these labels or categorisations, however, fail to capture the highly decentralised and fragmented nature of many regulatory systems, and the deployment of the term 'self'regulation, even with such elaborate qualifications, becomes analytically highly questionable. But merely responding by adopting the alternative label of 'hybrid' regulation is not in itself enough. Rather the nature and potentials of that hybridity have to be closely analysed if we are to proceed in any of the analytical or normative debates. It is argued that adopting an enrolment perspective can facilitate the analysis of decentred regulation, for it allows us to capture in more detail the nature of hybridity, and facilitate its development and deployment as a regulatory strategy.

An enrolment analysis focuses on actors, their regulatory capacities, the potential or actual functions they play within a regulatory system, and the nature of their interrelationship. It asks

\footnotetext{
38 FSA Handbook SYSC and APER.

39 For discussion see Black, supra n 1 (2001).

40 Ibid.
} 
what regulatory capacities they potentially possess, how those might change over time, and thus what regulatory functions they might be best placed to perform. It also facilitates both pragmatic and normative assessments of a regulatory system. Moreover, and of specific relevance to contemporary financial services regulation, it has a bearing on the risk-based approach to regulation that the FSA is explicitly adopting, and to debates on the accountability of the system.

\subsection{Actors}

Financial services regulation is characterised by an extremely wide range of actors who are or potentially could be involved in the regulatory process, particularly if the international dimension is included. The range of actors currently involved varies with the specific regulatory issue being focused on - not all are involved in every issue. They include, however, at least the following:

- International financial institutions (World Bank, International Monetary Fund (IMF)).

- International governmental standard-setting and policy bodies (eg, Bank of International Settlements and committees including the Basel Committee on Banking Supervision (BCBS), IOSCO, International Association of Insurance Regulators (IAIS), Financial Stability Forum (FSF), Financial Action Task Force (FATF), Joint Forum).

- International non-governmental issue and standard-setting bodies (eg, International Institute of Financiers, International Swaps and Derivatives Association (ISDA), International Securities Markets Association (ISMA); Bond Market Association.

- EU institutions, European Securities Committee and European Securities Regulators Committee. $^{41}$

- National regulators in other countries, including central banks, agencies and government departments.

- UK national-level statutory regulators/departments (FSA, Treasury).

- UK national-level organisations: recognised investment exchanges, recognised clearing houses, Lloyds, Panel, professional bodies, trade associations (eg, Association British Insurers (ABI), Association of Unit Trust Investment Funds (AUTIF), Association of Investment Trust Companies (AITC), British Bankers' Association (BBA), Consumers' Association, National Consumers' Council, other action and pressure groups (eg, Institute of Public Policy Research, the Retirement Income Working Party).

- $\quad$ Market actors:

- Gatekeepers - persons who control key resources that firms need: credit ratings agencies, insurers, auditors, internet service providers.

- Advisors - legal, management (including risk management) and IT consultants, accountants and other 'knowledge intermediaries'.

- Competitors and professional counterparties.

- Consumers.

- Regulated firm.

${ }^{41}$ The latter was set up in 2001 following recommendations in the Lamfalussy Report: Final Report of the Committee of Wise Men on the Regulation of European Securities Markets. Brussels, February 2001. 
- Individuals within the firm, including compliance officers, executives, back office and front office staff.

- Influential individuals, eg, 'policy entrepreneurs' and 'grey panthers'.

- Courts.

\subsection{Regulatory capacities}

Regulatory capacity is the actual or potential possession of resources plus the existence of actual or potential conditions that make it likely that those resources will be deployed both now and in the future in such a way as to further the identified goals of the regulatory system or resolve identified problems, however vague and contradictory those might be. Those resources are: information, expertise, financial and economic resources, authority and legitimacy, strategic position and organisational capacity. ${ }^{42}$

An actor might possess a resource directly or indirectly. Indirect possession of a resource, that is, that the actor has access to the resources of others, draws attention to the capacity-enhancing potential of interconnections between actors, discussed below. An actor may also be a resource for others, which again is linked to the capacity-expanding potentials of enrolment. For example, the fact that a particular actor is requiring a certain form of conduct might provide leverage to another actor who is better placed to affect the relevant behaviour. Thus a regulator may be a resource for a compliance officer: the fact that an enforcement official is coming down hard on a regulated firm might give a compliance officer the leverage $\mathrm{s} /$ he needs to ensure that management take the issue seriously. ${ }^{43}$ Or a private sector advisor (eg, management consultant) may be a resource for a regulatory official or manager within a firm seeking to implement internal management changes, helping them to overcome internal resistance to such changes. $^{44}$

Assessing the regulatory capacity of each potential actor is necessarily a detailed task that can only be done with respect to each individual actor and each regulatory system. Nevertheless, for the purposes of illustration, a summary table of the broad nature of the regulatory capacities of a number of actors is outlined in Appendix 1.

\subsection{Regulatory resources, capacities and functions: some examples}

Different regulatory resources are relevant for the performance of each of the different regulatory functions: goal identification and standard-setting, information gathering, and behaviour modification (the remaining regulatory 'tools'). In assessing a regulatory system, or in seeking to think strategically about its development, it is suggested that the potential role of each actor, in the sense of the regulatory function that it could perform, should be thought of in

\footnotetext{
42 For discussion see Black, J. (2003) 'Enrolling Actors in Regulatory Systems: Examples from UK Financial Services Regulation', Public Law (Spring 2003): 63-91.

43 Parker, C. (2002) The Open Corporation: Self Regulation and Corporate Citizenship. Cambridge, CUP.

44 Saint-Martin, D. (2000) Building the New Managerialist State. Oxford, OUP, p198.
} 
relation to the potential regulatory capacity that each possesses and how that capacity is likely to change over time. For it is important to remember that all will not necessarily remain equal: regulatory capacity is likely to change, and indeed the very fact of enrolment may alter the actor's behaviour in a way that was neither foreseen nor intended. It is also an exercise which has to be undertaken in depth with respect to each actor. Again for illustrative purposes only, the discussion below uses this analytical framework to suggest the potential regulatory role of various actors.

The international financial institutions, the IMF and the World Bank, have recently begun to play a role in international financial regulation and there is much debate as to whether that role should be expanded, and/or whether a separate international financial regulator should be created. ${ }^{45}$ Following a succession of financial crises, in May 1999 the IMF and the World Bank launched the Financial Sector Assessment Programme (FSAP), part of which entails monitoring the implementation of seven sets of standards issued by six inter-governmental bodies, including the IMF. ${ }^{46}$ The findings feed into the IMF's Financial System Stability Assessments (FSSA), the Bank's Financial Sector Assessments (FSA), and separately into a Report on the Observance of Standards and Codes (ROSC). ${ }^{47}$ The reason for incorporating assessments of compliance with these standards is that it is felt that such assessments 'help to identify vulnerabilities, gaps in regulatory structures and practices, and medium-term reform and development needs and priorities. They also help country authorities to evaluate their own systems against international benchmarks. ${ }^{48}$

The IMF and World Bank clearly have some valuable resources that could be deployed in a regulatory process, as indicated in Appendix 1. Critically, however, they lack expertise in certain key areas, for example corporate governance and insolvency, which reduces their ability to act as standard-setters and may hamper their ability to assess compliance adequately with the standards. In terms of their organisational capacity, they both clearly are large organisations, but they are moving into new areas and their ability to respond to the requirements of the new role may test that organisational capacity. Similarly, whilst they have the potential to wield quite significant sanctions and incentives, that ability is tied to their role as purse-holder, so is dependent on the financial needs of the country in question. In the absence of the ability to use the terms of financial assistance packages to require compliance, their capacity to ensure

45 Eatwell, J. and Taylor, L. (2000) Global Finance at Risk: The Case for International Regulation. Cambridge, Polity Press.

46 These are: IMF, Special Data Dissemination Standard / General Data Dissemination Standard; IMF, Code of Good Practices on Fiscal Transparency; IMF, Code of Good Practices on Transparency in Monetary and Financial Policies; BCBS, Core Principles for Effective Banking Supervision; IOSCO, Objectives and Principles for International Securities Regulation; IAIS, Insurance Supervisory Principles; The Committee on Payments and Settlements Systems, Core Principles for Systemically Important Payments Systems.

47 See IMF (2000) Financial Sector Assessment Programme: Review and Issues Going Forward (November 2000); IMF and World Bank (2000) Reports on the Observance of Standards and Codes (ROSCs): An Update (March 2000). In addition to the above codes the ROSC also assesses compliance with the OECD's Principles of Corporate Governance; the International Accounting Standards Committee's International Accounting Standards; the International Federation of Accountants' International Standards on Auditing, and, in the future, compliance with standards on insolvency and creditor rights.

48 IMF (2001) Assessing the Implementation of Standards - an IMF Review of Experience and Next Steps (PIN No. 01/17, March 2001). 
implementation of standards is dependent on the authority that their findings are given by other countries, and whether or not such countries feel some peer pressure from the international community to raise their standards. These are not factors that the international financial institutions can control, however. In terms of the regulatory function that they are well placed to perform, therefore, they are well placed to gather particular types of information (on the behaviour of national regulators, though not of those they are regulating), and in certain circumstances might be well placed to modify behaviour of national governments. They do not occupy the same strategic position vis-à-vis all countries however, and in its absence have only indirect tools at their disposal to ensure implementation. They are also arguably poorly placed at present to set standards given their lack of expertise in key areas, though given their membership they do have wider authority and legitimacy than non-governmental, though more expert, bodies.

In contrast, as an example of an international standard-setting body, the Basel Committee on Banking Supervision (BCBS) is a highly effective standard-setter. ${ }^{49}$ The most important resources for any international standard-setting body are expertise, authority and legitimacy, followed closely by information, and BCBS possesses, or has access to, all of these. BCBS, like other international standard-setters, is cross-jurisdictional, although not global: its jurisdiction is formally confined to its members. It has considerable authority in the financial world, stemming initially from its expertise, but more recently from changes in its policymaking processes. The scope of its authority and legitimacy is extending beyond its members as it widens its consultation processes to include non-G10 countries including lesser developed countries. As a result, non-members are increasingly likely to accept its standards and modify their behaviour accordingly. BCBS does not, however, occupy a key strategic position in the sense of controlling a resource that a national government needs (national governments being in this case the direct targets of the regulation), and so is rarely, if ever, able on its own to ensure adoption and implementation of standards. Like international financial institutions, it is principally dependent on the social and political pressures exerted by the international community for the adoption of its standards. In this regard, BCBS has considerable authority and its standards are implemented as a matter of course by the G10 members that comprise its membership and by those outside - facilitated now by the FSAP project. It is well placed to gather and disperse information on activities within its members' jurisdictions, at least as regards regulatory compliance by national regulators and to an extent by regulated firms ${ }^{50}$ as well as market practices. ${ }^{51}$ Thus, in terms of regulatory function, it is strong in gathering certain types of information and in standard-setting but will rely principally on others to ensure that behaviour is modified as required.

Moving to the national level, as a statute-based regulator, the FSA clearly possesses the resources of legal authority and legal legitimacy, which can serve as some compensation for

\footnotetext{
49 For a broader discussion on the role of international standard-setting bodies see Giovanoli, M. (2000) 'A New Architecture for the Global Financial Market: Legal Aspects of International Financial Standard Setting' in M. Giovanoli (ed) (2000), International Monetary Law: Issues for the New Millennium. Oxford, OUP.

50 Eg, BCBS (2001) Public Disclosures by Banks: Results of the 1999 Disclosure Survey. Basel, BIS (April 2001); BCBS (2000) Range of Practices in Banks Internal Ratings Systems. Basel, BIS (January 2000).

51 Eg, BIS (2002) Quarterly Review: International Banking and Financial Market Developments. Basel, BIS (March 2002).
} 
any lack of perceived authority or legitimacy coming from those it seeks to regulate or on whose behalf it seeks regulate. Second, it occupies a strategic position in that it controls access to the ability to engage in investment services business through the statutory system of authorisations and permissions, and it is able to inflict a range of credible sanctions on a firm directly, subject to an appeals process. It is also able to make life uncomfortable for a firm through its administrative practices: more frequent and more intrusive monitoring, for example. In terms of organisational capacity, in the absence of a detailed study on the functioning of the organisation only very general remarks can be made. There is some evidence that systems are developing in certain areas for information collation and assessment ${ }^{52}$ and for ensuring consistent monitoring and enforcement practices, ${ }^{53}$ and for attempting to ensure crossorganisational information flows, for example as part of the risk assessment process (the 'risk' being assessed is that the FSA will not meet its objectives), ${ }^{54}$ but not enough research has been done to assess its organisational capacity in any detail. In terms of expertise and information, it clearly faces the problem that any regulator faces, which is an asymmetry of both. The FSA has quite extensive powers to gather information, including the power to launch industry-wide investigations into past and current practices, ${ }^{55}$ but ensuring that the relevant information is given remains a difficult task. With respect to expertise, the asymmetry between regulator and regulated is exacerbated by the extraordinarily wide disparities in pay between the two sectors. The current contraction in the investment banking sector is enabling the FSA to improve the quality of its staff and to reduce staff turnover (also illustrating how changes in the external environment can affect the possession of resources), but the Practitioner Panel have nonetheless expressed concern at the expertise of its front-line staff and have launched a review of firms' assessment of the FSA's competence and the costs of compliance. ${ }^{56}$ So, like any national regulator, its capacity to perform its regulatory functions is mixed. ${ }^{57}$

A quite different type of actor are advisors, or 'knowledge intermediaries', for example IT consultants, management consultants, lawyers, accountants. Advisors possess information and expertise, and their influence can be extensive, ${ }^{58}$ but they are not usually seen as having a potential role to play in the regulatory process. They could nonetheless be a potentially useful resource for the FSA, however, and indeed the FSA implicitly relies on them to improve the organisational capacity of firms, though this reliance might go unrecognised. They have the potential to gather and convey information on an aggregate and anonymous basis about firms' practices, though clearly the laws on confidentiality and fiduciary duties will prevent any

\footnotetext{
52 Eg, Risk Assessment Division.

53 Eg, Market Conduct team in the Markets and Exchanges Division.

54 FSA, A New Regulator for the New Millennium, supra n 2; Foot, M. (undated) 'Our New Approach to RiskBased Regulation: What Will be Different for Firms?', available from www.fsa.gov.uk/pubs/speeches/sp69.html.

55 FSMA Part XI.

56 Financial Times, $23^{\text {rd }}$ June 2002.

57 For criticisms of the expertise of the SEC see GAO, Reports to Congressional Committees: SEC, Human Capital Challenges Require Management Attention (GAO-01-947, September 2001).
}

58 On the influence of management consultants on public management processes see Saint-Martin, D. (2000) Building the New Managerial State. Oxford, OUP. 
attributable information from being passed on. Their potential to modify behaviour is dependent largely on their expertise, through which they derive their authority, and their strategic position. The former will derive from the reputation of their industry sector as a whole, and their own reputation in particular. The latter might not be strong, particularly as advice is always available from another source, and unlike auditors or actuaries, the legal aspects of the regulatory structure do not confer a strategic position on them (eg, their advice or verification is not a legal requirement). Most notably, however, advisors do not have widespread authority or legitimacy which clearly limits their ability to act as standard-setters or to modify behaviour by imposing sanctions. Thus, their potential regulatory role is likely to be confined, both normatively and in terms of effectiveness, to information gathering and dispersal through techniques of education and persuasion combined with any authoritative position they hold as a result of their expertise and associated reputation.

A set of actors whose actual and potential role in the regulatory system is currently much debated is ratings agencies, be they of credit or performance. Such agencies are key actors within the market. ${ }^{59}$ By providing information to the market (albeit based on information provided to them by the firm) they can substantially reduce transaction costs. Firms rely on credit ratings to provide them with an assessment of the creditworthiness of counterparties; advisors and others rely on the ratings of investment funds to provide them with information concerning, amongst other things, the volatility and performance of the fund. Credit ratings agencies are explicitly enrolled in some regulatory regimes, for example in the US, ${ }^{60}$ and the BCBS proposals for the new Capital Accord propose to expand their enrolment, by allowing banks in conjunction with regulators to use credit ratings to calibrate the risks associated with different loans. ${ }^{61}$ In terms of their potential regulatory capacity, ratings agencies score highly: they have access to information, expertise, authority within the financial community based on their reputation, and strategic position: the rating can significantly affect a firm's market position. They are already key regulatory actors in their own right, and their potential for enrolment within a formal, national legal system is clear. However, various reservations have been expressed at their inclusion. These relate first to whether it is appropriate to use their assessments for regulatory purposes. This is not based on their legitimacy, or whether or not they are themselves regulated, but on whether or not information produced for market purposes can be used for regulatory purposes without distorting the latter. Thus, ratings agencies tend to raise ratings in economic upturns, and lower them in recessions. This may be a valid market approach, but incorporation of the ratings in prudential supervision would mean that banks could lower their reserves in upturns, but increase them in downturns, the opposite of the optimal approach for capital standards suggested by financial economists. ${ }^{62}$

59 On credit ratings agencies see generally Schwarcz, SL. (1998) 'The Universal Language of Cross-Border Finance', Duke Journal of Comparative and International Law, 8 (2): 235-254 and 'The Role of Rating Agencies in Global Market Regulation' in E. Ferran and C. Goodhart (2001) Regulating Financial Services and Markets in the $21^{\text {st }}$ Century. Oxford, Hart Publishing.

60 For details see BCBS (2000) Credit Ratings and Complementary Sources of Credit Quality Information, Working Paper no. 3. Basel (August 2000).

61 BCBS (2001) Consultative Document: Overview of the New Basel Capital Accord. Basel, BIS; BCBS (2003) The New Basle Capital Accord, Third Consultative Paper Basle, BIS.

62 Jackson, H. (2001) 'The Role of Credit Rating Agencies in the Establishment of Capital Standards for Financial Institutions in a Global Economy' in Ferran and Goodhart, supra n 58, citing Altman, E. and Sanders, A. (2000) 
Second, the concern is whether credit ratings agencies would use their resources in a way that would further the goals of the regulatory system, or indeed whether the very fact of their enrolment would itself alter the internal incentives or culture, for example, with the result that ratings become too lenient, and the potential capacity represented by their resources is not translated into actual capacity. ${ }^{63}$ Third, regulators need to be sure that the signal that they are relying on, the credit rating, in fact incorporates the information that they think it does. One recent example illustrates the potential for mutual misinterpretation of information. The FSA recently criticised a credit rating agency for incorporating into its ratings the FSA's own risk assessment of a firm. ${ }^{64}$ However, as discussed further below, the FSA's definition of risk is whether there is a risk to the FSA achieving its objectives. Their risk assessment of an individual firm is a function of the probability of harm occurring multiplied by the magnitude of the harm in scale and scope. ${ }^{65}$ Thus, failure of a large firm will necessarily have a bigger impact than that of a smaller firm, so large firms may well end up with a higher risk rating, but it is one unrelated to the stability of their financial position. The credit rating given thus incorporated a misinterpretation of the FSA's own assessment. In this case the FSA were aware of the issue; however, the incident highlights the potential for distortion through double misinterpretation. The regulator could misinterpret and incorporate into its risk assessment of a firm information which itself contains a misinterpretation of the regulator's prior assessment of that firm.

Finally, individual firms are key actors in any regulatory system, for any system in practice relies heavily on the regulatory capacity of the individual firms that it regulates for its effectiveness. In practice, firms are expected to perform all regulatory functions: to set standards to be attained, even if that entails simply (though often it is a far from simple task) communicating the regulatory standards, to gather information on practices and to modify behaviour. The issue in question when considering the regulatory firm thus is not so much what tasks could they be given, but given that they are expected to perform every task, how might their capacity to do so be enhanced. Firms' capacity clearly varies widely both at the aggregate organisational level, and within the organisation. Government regulators can provide firms with some of the resources they need to improve their regulatory capacity, for example by imposing mandatory disclosure requirements on firms' counterparties thereby giving them the information they need in order to base decisions. But there may also be limits to that capacity. For example, reliance is increasingly being placed on firms to monitor their counterparties and to take into account a wide range of information in making decisions on whether or not to deal with that counterparty or if so on what terms. The information that firms are expected (not necessarily by law) to take into account includes the firm's risk position disclosures, their jurisdiction and the compliance of that jurisdiction with a range of regulatory standards

\footnotetext{
'An Analysis and Critique of the BIS Proposal on Capital Adequacy and Ratings', available at http://www.stern.nyu.edu/ ealtman/bis.pdf).

63 See eg, ibid, and the US Shadow Financial Regulatory Committee, supra $\mathrm{n} 7$.

64 Financial Times, $14^{\text {th }}$ June 2002.

65 FSA, A New Regulator for the New Millenium, supra $\mathrm{n} 2$.
} 
including money laundering. ${ }^{66}$ However, it is the trader in effect who is making these decisions, and their decision processes are not necessarily the rationalistic processes that regulators may wish them to be; rather they are chaotic and based on myths, stories and rules of thumb. ${ }^{67}$ Moreover, even where a more sober consideration of information does occur, from the trader's point of view the information might not be presented in a way which they can readily use, ${ }^{68}$ and other information might be more relevant. As one international bond trader commented in response to the Financial Stability Forum's survey on implementation of standards, information in the ROSC reports was 'a small detail in an ocean of institutional imperfection and political dynamics'. ${ }^{69}$ Attempts to utilise strategies of information giving to 'super-rationalise' firms' decision processes is thus in turn dependent on the willingness and ability of such processes to be 'rationalised' in that way.

\subsection{Responding to changes in regulatory capacity}

As noted above, any assessment of regulatory capacity is liable to become outdated as soon as it is made, for changes in the possession of resources and in the internal and external environment will affect that capacity. It might also be the case that experience shows that assessments of capacity were in fact wrong, or over-optimistic, when made. The different forms of enrolment of organised exchanges and over-the-counter (OTC) markets provide good examples of both situations; it also provides an interesting example of leaving the choice of how or whether to be enrolled up to the regulated firm.

At present under the FSMA, as under the Financial Services Act 1986, a firm or organisation can function as an exchange or trading platform without having to seek the status of a recognised investment exchange (RIE). ${ }^{70}$ It operates instead under the rules that apply to authorised persons. In effect, the firm has a choice: it can either apply for RIE status, in which case it will be required to perform all the key regulatory functions of standard-setting, information gathering and behaviour modification with respect to its members, or it can apply for authorisation through the normal route, in which case it is not required to act in a such way. This choice as to whether or not to be enrolled as full-scale regulators has been cited as one of the key commercial attractions of operating in the UK. ${ }^{71}$

66 See eg, Financial Stability Forum, Report of the Follow-Up Group on Incentives to Foster Implementation of $\underline{\text { Standards (FSF, August 2000) and Final Report of the Follow-Up Group on Incentives to Foster Implementation of }}$ Standards (FSF, September 2001).

67 BCBS (1999) Banks' Interaction with Highly Leveraged Institutions. Basel (January 1999); Willman, P., Fenton-O'Creery, M., Nicholson, N. and Soane, E. (2002) 'Traders, Managers and Loss Aversion in Investment Banking: A Field Study', Accounting, Organization and Society, 27 (1-2): 85-98.

$68 \mathrm{Eg}$, criticisms in FSF surveys of the format of ROSCs by firms: supra $\mathrm{n} 65$.

69 FSF, Final Report, supra n 65, 32.

70 For discussion see FSA, DP 2, supra n 33.

71 FSA (2001), The FSA's Approach to Regulation of the Market Infrastructure: Feedback on Discussion Paper (June 2001), para 3.42. 
However, the example of RIEs and OTC markets also illustrates the factors that can prompt changes in regulatory capacity, and thus suggest changes in the enrolment strategy adopted. At present, changes in the market structure are such that there is a disaggregation of organised exchanges, RIEs, and a centralisation occurring within the OTC markets with the rapid development of alternative trading systems (ATSs). These changes in the market environment have prompted a move on the one hand to reduce the extent to which RIEs are enrolled within the regulatory system, and on the other to increase the enrolment of ATSs. For changes in the market context are calling into question, first, the extent to which reliance can continue to be placed on the regulatory capacity of recognised exchanges, and, second, on whether those who operate alternative trading platforms, ${ }^{72}$ which have the same functionality as recognised exchanges, should themselves be more closely enrolled. With respect to RIEs, increased competition between exchanges and ATSs has called into question the extent to which recognised exchanges can continue to be relied upon to fulfil their regulatory role. This is partly because commercial pressures and in particular demutualisation has, or may, result in them being less willing to act as disinterested and objective regulators, but also partly because even if they did, compliance might not be as forthcoming as it was: members (notably those who themselves operate ATSs) are said to be increasingly unwilling to co-operate with an organisation which they see as its competitor. ${ }^{73}$ It was in response to these concerns that the regulatory role of the Stock Exchange was reduced under the FSMA, when it lost its status as the competent authority for implementation of the listing rules: it was de-enrolled in this respect. Further, arising from concerns in the past that the RIEs were not responding adequately to regulatory problems that arose on their markets, including market manipulation practices, the relationship with the RIEs has shifted to a more hierarchical one. Under the FSMA, the FSA has the power to issue directions to the RIEs (and recognised clearing houses) if it considers that they are not complying with the conditions of their recognition. ${ }^{74}$ This arguably corrects a weakness in the way in which they were enrolled in the 1986 Act, as that Act allowed for no change in the relationship between the RIE and the Securities and Investments Board (SIB) should the prior assessment of the RIE's regulatory capacity turn out to be wrong, or that capacity change. Moreover, it also led to a problem of misplaced expectations and a mismatch between the allocation of regulatory capacity and structures of accountability. The expectation of the wider regulated community and of those outside the regulatory system was that the SIB would be able to act, whereas it could not. Further, the accountability structures were orientated around the SIB: the RIEs were accountable only to their members. The SIB, however, had attenuated capacity, because it had no formal legal authority, to require the RIEs to act differently.

\footnotetext{
72 Defined by the Committee of European Securities Regulators (CESR) as 'an entity which, without being regulated as an exchange, operates a multilateral system that brings together multiple third party buying and selling interests in financial instruments - in the system and according to non-discretionary rules set by the system's operator - in a way that forms, or results in a contract': CESR, Proposed Standards for Alternative Trading Systems, CESR 02/001 (January 2002), para 13.

73 FSA, DP 2, supra n 70. For expressions of similar concerns in the US see GAO, Reports to Congress: Securities Markets - Competition and Multiple Regulators Heighten Concerns about Competition (GAO 02-362, Washington DC, May 2002).

74 FSMA s 296.
} 
Thus, changes in the market and political environment have altered the regulatory capacity of RIEs in several key respects: their strategic position has been eroded as their near-monopoly positions have been challenged by the proliferation of alternative trading platforms for the same investments, their authority has been challenged by their own members who may operate in competition with them, and their incentives, always split between acting in a regulatory and in a commercial capacity, have moved substantially in the direction of the latter. However, whilst there is concern at the eroding regulatory capacity of RIEs, no change in the current practice of the enrolment of RIEs is proposed. On the other hand, there are indications that the enrolment of ATSs in the regulatory system is likely to increase, and that they will be required to act as surrogate regulators, though to a lesser extent than RIEs. The Committee of European Securities Regulators (CESR) has proposed that ATSs should be required, amongst other things, to monitor compliance with their own contractual rules, and to establish arrangements with their home country regulator to monitor activities on the ATS with a view to detecting unfair practices and market abuse. ${ }^{75}$ In proposing the former requirement, the proposals extend the regulatory responsibilities of ATSs much further than the FSA indicated that it would in its own discussion paper on the issue. ${ }^{76}$ In both cases, the proposals are, in effect, that the national regulator should enrol the ATS's resources of information and strategic position in the achievement of their own regulatory objectives, with the ATSs primarily conducting the function of information gathering in both cases, though it is not clear from the CESR proposals what the expectations are for what ATSs should do if they detect non-compliance.

\section{Using enrolment analysis to 'map' financial services regulation}

Using an enrolment perspective to analyse contemporary UK financial services regulation provides an alternative perspective from a tools-based analysis in that it forces the focus onto five dimensions of the regulatory system in particular: first, the relative regulatory capacities of actors; second, the distribution of regulatory functions between a multitude of actors; third, the resources that are being enrolled; fourth, the nature of the relationships that exist between them; and fifth, the character of the enrolment.

The first has been discussed above, and two further dimensions will be focused on here: the distribution of functions between actors, and the character of the enrolment. ${ }^{77}$ With respect to the distribution of functions, one of the clearest examples of enrolment of both governmental and other actors in the regulatory process is in the function of standard-setting. Financial services regulation is characterised by a network of interlocking rules, both at the national and international level. At the national level, examples include reliance on the guidance of the Joint Money Laundering Steering Group (JMLSG) to interpret the Money Laundering Regulations, and the explicit decision by the FSA to rely on the JMLSG guidance on customer identification

75 CESR, Proposed Standards for Alternative Trading Systems, supra $\mathrm{n} 71$, standards 4 and 5. These would apply only to ATSs that are price makers.

76 FSA, DP 2, supra n 33, and DP 2 feedback, supra n 70; this policy has developed further: see FSA (2003), Alternative Trading Systems: Feedback on CP 153 and made text.

77 For discussion of the other two, see Black, supra $\mathrm{n} 41$. 
rather than write its own rules, ${ }^{78}$ reliance on the Council of Mortgage Lenders (CML) code to regulate mortgage lending, the BBA's code to regulate retail deposit taking and the agreement between the BBA and FSA that the FSA's rules on the Key Features requirements for cash individual savings accounts (ISAs) will be the same as the BBA's rules, given their mutual jurisdiction on the issue. Further, compliance with the rules of other actors can provide safe harbours with respect to FSA requirements. For example, under the market abuse regime, compliance with the rules of the Takeover Panel on the timing, dissemination or availability of information, or the content and standard of care applicable to a disclosure or release of information also provides a safe harbour from the market abuse regime, as long as the conduct is not a breach of a General Principle of the Code. ${ }^{79}$ The FSA's formal relationship with these bodies varies. It has no formal powers with respect to the BBA and CML; however, both know that their regulatory lifespan is limited, giving the FSA informal power over them. In the case of the RIEs, as noted, the FSA has the power to order the RIEs to alter their rules or practices if they are failing or likely to fail to satisfy the requirements for recognition or have failed to comply with any other obligation imposed under the Act. ${ }^{80}$ It has no powers over the JMLSG or the professional bodies, however, although neither is it excluded from ceasing to enrol those bodies and writing its own rules in areas where their jurisdictions overlap, or indeed from withdrawing safe harbour status from those rules of other bodies on which the status is currently conferred.

The regulatory system also enrols a range of actors in the function of information gathering. The role of accountants, auditors and lawyers in monitoring and verifying compliance are obvious examples. Another is the regulatory system for money laundering, which requires firms to report suspicious transactions to the National Criminal Intelligence Service (NCIS), and the FSA places firms under an obligation to ensure that their systems are such that they can identify such transactions. Under the FSA regime, whistleblowers are given statutory protection, in an effort to enhance the information on malpractices. ${ }^{81}$ As noted above, it is proposed that ATSs should be put under a duty to monitor trades with a view to detecting unfair practices and market abuse and reporting these to the FSA. ${ }^{82}$

With respect to other strategies of behaviour modification, the regulatory system enrols a number of actors in the function of information dispersal and verification, for example, and not simply under the mandatory disclosure regimes. Information services, such as Reuters, are relied upon to ensure price information is widely disseminated, facilitating the functioning of the market. The FSA has contracted out its function of providing information to the market to a

\footnotetext{
78 FSA Handbook ML 3.1.4G; FSA, Money Laundering: The FSA's New Role: Policy Statement on Consultation and Decisions on Rules (January 2001).

79 FSA Handbook MAR 1.7.10E.

80 FSMA s 296.

81 Public Interest Disclosure Act 1998; FSA CP 101, Whistleblowing, the FSA and the Financial Services Industry (July 2001); Policy Statement, Whistleblowing, the FSA and the Financial Services Industry: Feedback on CP 101 and made text (April 2002).
}

82 See further below. 
number of specialist information providers. ${ }^{83}$ Ratings agencies are relied upon to give information about firms' financial stability, for example, or the performance and volatility of investment funds. Trade associations have been used to disseminate information about the FSA's expectations and likely requirements, for example in the early stages of establishing the review of personal pensions. The media are relied upon to disseminate information about personal finance products which it is deemed too complex to give to consumers directly. The FSA is itself enrolled in the regulatory system for money laundering, having agreed with the NCIS to disseminate information on countries which do not comply with international guidelines.

The function of imposing sanctions is also dispersed between a range of actors, on whom the FSA implicitly or explicitly relies. Again, the role of professional bodies in disciplining members is an obvious example, as is the requirement on the RIEs to enforce their rules. Others noted above are the reliance on the reputation effects of being shown to be in noncompliance: the practice of 'cold shouldering' for example, or the assessment and verification by trade associations of compliance with their rules (as in the case of the ABI's code on disclosures with respect to with-profits policies). ${ }^{84}$

Finally, some are enrolled to perform all of the regulatory functions: the roles of the BBA and CML and associated enforcement bodies have been noted above, as has the role of RIEs. Most notable is the increasingly explicit enrolment of firms to perform the regulatory functions. As noted above, any regulatory system enrols firms whether implicitly or explicitly. What is striking about financial services regulation is the shift to more explicit enrolment, manifested in, for example, strategies of meta-regulation (the audit of audits), of the deployment of firms' own assessments of their risk positions in the regulator's assessments of capital adequacy, and the placing of responsibilities directly on individuals within the organisation under the approved persons regime.

In these strategies of enrolment a number of different types of relationships may be involved. They may be ones of mutual dependency and take on the characteristics of networks, they may be hierarchical, they may take the form of contracting, or be some combination of each. ${ }^{85}$ The character of the enrolment also varies. It may be legally required, for example the mutual enrolment of the FSA and the Takeover Panel, or of 'home' and 'host' regulators under the EU passporting regime. It may not be specifically legally mandated, but still be formalised, such as Memoranda of Understanding (MOUs) with other national governmental bodies (for example the Tripartite Standing Committee of the FSA, the Bank of England and the Treasury, the partnership agreement between the FSA and the National Criminal Investigation Service) or international bodies (MOUs between regulators, or membership of intergovernmental bodies). It may be informal but explicit, such as interchanges with trade associations, for example, and relying on them to disseminate information to members. It may be informal and implicit, for

83 FSA, Review of the UK Mechanism for Disseminating Regulatory Information by Listed Companies (CP 92, May 2001); FSA, Proposed Changes to the UK Mechanism for Disseminating Regulatory Information by Listed Companies: Feedback on CP 92 and made text (Policy Statement 92, November 2001).

84 ABI (2001) Raising Standards Quality Mark Scheme. London, ABI. Compliance is assessed by the Pensions Protection Investment and Accreditation Board.

85 See further Black, supra n 41. 
example relying on the rational decision processes of consumers or of individual traders within firms, or on insurance companies, advisors, ratings agencies, counterparties to shape the incentives of firms (or of individuals within firms) whose behaviour the FSA is trying to modify, or to take a more extensive role, for example to impose or monitor compliance with requirements and impose sanctions for their breach.

Using an enrolment-based analysis thus provides a more nuanced understanding and mapping of contemporary financial services regulation than a tools-based analysis that relies on ever more elaborate qualifications to the term 'self-regulation'. It allows us to see the form that fragmentation and hybridisation takes in different aspects of the regulatory regime. It draws attention to the relative regulatory capacities of actors and the distribution of functions between them, to their interrelationships, and to the different degrees of formality or informality, implicitness or explicitness that enrolment can take.

\section{Using enrolment analysis to assess the regulatory system}

An enrolment approach to regulation does not only facilitate a different and more nuanced kind of mapping than a tools-based analysis, however, it also provides a pragmatic and normative criterion against which to assess a regulatory system. By way of example of the former, ${ }^{86}$ the current proposals for the role of the appointed actuary in the regulation of life insurance companies can be assessed by considering their potential regulatory capacity and whether the proposals will fully utilise that capacity.

The FSA argue that the role of the appointed actuary (AA) is an unusual one in the current regulatory system in that specific regulatory responsibilities are placed on the AA, not on the firm. ${ }^{87}$ Historically, this was true. However, given the introduction of the approved persons regime this position is in fact no longer so unusual, and the AA is an approved person under that regime. What was unusual was the extent to which the AA was relied upon explicitly by regulatory authorities to act as a surrogate regulator. ${ }^{88}$ To quote the Institute and Faculty of Actuaries: 'The process of valuation, reporting and certification by the Appointed Actuary enables the Insurance Directorate to monitor the Company's financial progress without carrying out its own detailed investigations. ${ }^{89}$ AAs have a relatively high potential regulatory capacity, making their enrolment an advantageous strategy for the regulators. In particular, they possess expertise, and their resources have been enhanced by the regulatory system which gives them access to information and strategic position. However, there are suggestions that their authority within the firm might vary, that their authority and legitimacy outside the firm might be questioned, and that their organisational capacity might be limited (in the case of

\footnotetext{
86 The latter is considered in Section 8 on accountability, infra.

87 FSA (2002), With-Profits Review Issues Paper 5: Governance and the Role of the Appointed Actuary (March 2002), para 70 .

88 The current duties of the appointed actuary, and of the firm to the AA, are set out in FSA Handbook, Supervision Manual, Chapter 4 (SUP 4).

89 Institute and Faculty of Actuaries, The Role of the Appointed Actuary (May 2000).
} 
specialist firms undertaking the role for many different life companies). Further, with respect to how those resources are likely to be used, internal and external factors indicate that there are significant pressures on AAs not to act as surrogate regulators.

Indeed, the weakness of the AA as a surrogate regulator was illustrated by the Equitable Life affair, and a number of factors have been suggested as contributing to this weakness. The FSA argues, for example, that changes in the market environment (demutualisation, increased competition and the drive to increase shareholder value) has put additional pressures on senior actuaries in firms and some have passed on the appointed actuary role to another actuary. As a consequence, appointed actuaries have been perceived by some to have become less influential in recent years in the management of life insurers: their authority within the firm has diminished. ${ }^{90}$ Further, changes in the incentives, perceptions and actionorientations of AAs have occurred, often because of the combination of the AA role with that of a senior executive role in the life company (as in Equitable Life), with the result that the independence of the AA which the regulatory regime was implicitly relying on has been lost. Consequently, reports into Equitable Life have concluded that this independence needed to be reinforced, for example by an independent external review of the AA's work. ${ }^{91}$

A potential regulatory strategy could, therefore, be to maintain their enrolment as a regulator of life companies, but bolster their regulatory capacity by enhancing their authority and legitimacy through external verification of their work, and by reducing the potential for conflicts of interest to distort the deployment of their resources by, for example, prohibiting them from holding certain senior executive positions within the life office. This could then be coupled with an expansion of their role (for example, a mandatory requirement to produce a Financial Condition Report, a prospective-looking report on risks to the firm's financial position which is aimed to enhance the board's decision-making). ${ }^{92}$

However, the FSA are considering reducing the reliance on the AA as a surrogate regulator, and instead placing its current responsibilities onto the board of directors. The requirement to have an AA would be removed, with the exception of those firms carrying on with-profits business who would still be required to have an AA to advise them on the use of their discretion in that area. However, if a board did have someone providing actuarial advice, that person would be an approved person and the actuarial function an approved function. Whether the current functions of the AA would be carried over into the approved persons regime is not yet decided; the main point is that the AA would no longer be responsible for attesting to reserves, for example, that would fall to the board. Whether there is to be an independent review of the AA (or person carrying out the actuarial function) is also still undecided, but it is proposed that the person holding the post should not also be a senior executive of the firm, and

90 FSA, With-Profits Review Issues Paper 5 (supra $\mathrm{n}$ 86) para 81.

91 FSA (2001), The Regulation of Equitable Life from 1 January 1999 to 8 December 2000 (September 2001) (Baird Report), para 7.3; Institute and Faculty of Actuaries (2001) The Report of the Corley Committee of Inquiry Regarding The Equitable Life Assurance Society (September 2001) (Corley Report), para 37.

92 As currently recommended by actuarial guidance (Institute and Faculty of Actuaries, Guidance Note 2); the Corley Report suggested the report should be mandatory (ibid, para 35). Whilst many AAs in life companies prepare one, in Equitable Life it did not. 
that person's work be included within the audit review. This latter proposal comes despite concerns by some respondents at the conflict of interest that auditors might be under (as they act for the shareholders, not the policyholders). A Financial Condition Report would be required, but should be prepared by the board. The only respect in which their regulatory role would be expanded would be by extending protection to whistleblowers, encouraging them to give information to the FSA. ${ }^{93}$

A capacity-based analysis would suggest that such an approach (assuming the current position is not in fact re-created in the definition of the actuarial function) unnecessarily discards a potentially valuable regulatory actor. The goal of emphasising the responsibilities of the board could still be attained by shifting some of the current 'signing off' responsibilities from the AA to the board. However, it is not clear why the AA could not still remain for all companies, complete with its professional responsibilities, and for its capacity to be enhanced in the ways suggested above. Moreover, the FSA will still need to address the issue of co-ordination with the actuarial profession, for it relies on the professional bodies to ensure the competence of the actuary, and presumably will continue to rely on them to provide detailed guidance in the performance of their role (whether they act under the title of AA or an approved person performing the actuarial function). Finally, although formal responsibility will rest with the board, in reality the board is likely to rely on the actuary's specialist advice: the FSA may therefore be mistaken in thinking that the result will actually be to make the board take their responsibilities more seriously. So whereas the FSA may think they are reducing the enrolment of the actuary in the regulatory system, this might not be the case in practice. Moreover, it was not initially proposed to have the actuary's advice, or indeed the board's decision, independently assessed by another actuary, a strategy that would really enhance the actuarial profession's regulatory capacity within the system as a whole. $^{94}$ Both points should, in turn, be relevant in the FSA's risk assessments.

\section{Implications of an enrolment analysis for the FSA's risk assessment process}

Using the analytical frame of enrolment thus enables us to recognise, analyse and assess the fragmentation of financial services regulation, even at the national level, despite the organisational consolidation introduced by the FSMA. However, the mapping exercise that it enables is not of purely academic interest. It has significant implications for the FSA for it illustrates the extent to which the FSA enrols, and relies, directly and indirectly, intentionally or unintentionally, on a wide range of actors for the attainment of its aims. The results of this analysis, it is suggested, should in turn feed into the risk assessment process which the FSA has said it will put at the heart of its regulatory strategy. For failure by any one of those actors may, depending on the circumstances and the structures built into the regulatory system, result in failure by the FSA to achieve its objectives.

\footnotetext{
93 Public Interest Disclosure Act 1998; approved persons are covered by the Act; it would have to be extended to cover appointed actuaries for with-profits companies.

${ }^{94}$ See now FSA (2003), With Profits Governance and the Role of Actuaries in Life Insurers: Feedback on CP 167, made and near final text (FSA, London).
} 
The relevance of the enrolment analysis to the FSA's risk assessment stems directly from the definition of 'risk' that the FSA are adopting. For in its 'risk-based' approach to supervision, 'risk' is defined explicitly as risk of failure to achieve the regulator's statutory objectives. ${ }^{95}$ It is not an assessment of, for example, the overall level of systemic risk within the markets, or of risks to consumers. Only indirectly does the FSA's risk approach incorporate such risk. Thus, for example, as one of the FSA's statutory objectives is maintenance of market confidence, ${ }^{96}$ the issue of systemic risk is relevant as it is one element that will affect market confidence, and thus might threaten the ability of the FSA to achieve this particular statutory objective. By identifying the actors involved, assessing their regulatory capacity and analysing the ways in which they are or might be enrolled in the regulatory system in the ways suggested above, the FSA would be able to assess the extent to which it is reliant on others to attain its regulatory objectives, and whether those actors in fact have the regulatory capacity necessary to perform the role for which they are enrolled. Moreover, it would facilitate analysis of whether other actors, not currently enrolled, should have their role expanded.

An enrolment analysis should also highlight the need for certain types of relationship to develop between the FSA and others in the regulatory system. These include, for example, the need for co-ordination when similar functions are being exercised (for example, disciplinary activities of the FSA and professional bodies, or interpretations of the same set of rules, as with the Takeover Panel); the need for co-operation where the relationship is one of high interdependency (for example, between other governmental and international bodies); or the need to change the nature of the relationship in response to another actor's conduct, as the model of responsive regulation and the regulatory pyramid, would suggest ${ }^{97}$ (as illustrated by the RIE example, above).

\section{Implications of an enrolment analysis for discussions of accountability}

The accountability of the regulatory system has been much discussed in parliamentary, practitioner and academic circles. ${ }^{98}$ However, all discussions have focused on the FSA. They have, in other words, taken a centred perspective. In contrast, the decentred perspective of regulation, of which the enrolment analysis is a natural extension, emphasises the fragmentation and hybridisation of regulatory systems. As the discussion above illustrates, financial services is no exception: the FSA is only one part of the financial services regulatory system, even at a national level, and even within the boundaries of its own legal jurisdiction. Thus analyses of accountability which focus only on the FSA are inevitably partial.

\footnotetext{
95 A New Regulator for a New Millenium, supra $\mathrm{n} 2$.

96 FSMA ss 2 and 3.

97 Ayres, I. and Braithwaite, J. (1992), Responsive Regulation. Oxford, OUP; Gunningham and Grabovsky, supra $\mathrm{n} 3$.

98 For an excellent discussion see Page, A. (2001) 'Regulating the Regulator - A Lawyer's Perspective' in Ferran and Goodhart (eds) supra n 38.
} 
Enhancing the accountability of the regulatory system is, however, a significant challenge. Analytically, there are three options. First, the FSA takes responsibility for the actions of all those that it enrols, so that the accountability of each actor is derivative on the accountability of the FSA. Second, that each enrolled actor is itself made directly accountable in some way to someone, be it the FSA, another part of the executive, the legislature, the courts, another regulatory actor, practitioners, consumers, or civil society more generally. Third, that there is some combination of the two.

In order to be meaningful, the first option, derivative or 'chain' accountability, is subject to two conditions for its effectiveness; it also has two significant drawbacks. The conditions are, first, that the FSA has the ability to direct the actions of the actors for whom it is held accountable in some way. In other words, for there to be a chain of accountability, there must be a chain of control. Second, the FSA has itself to be assessed as sufficiently accountable against at least one of three sets of criteria or models of accountability: legislative mandate, due process and oversight. $^{99}$ The drawbacks are that there is a limit to how long the chain of accountability can be for it to be credible, and that even if this option were adopted, it is unlikely to be sufficient, for actors are likely to be enrolled in a manner that is neither formal nor explicit, and over whom the FSA does not exercise the requisite control.

The second option is for each enrolled actor to be directly accountable, although to whom and for what remain open questions. One option is for actors to be subject to functional equivalents of the models of accountability familiar in public law: mandate, due process, oversight and redress. Mandate in this context would require that the actor has a mandate from those who it purports to regulate; it is an expression of the bestowal of authority. Due process in decisionmaking (including enforcement) would require, for example, actors to conform to basic principles of the rule of law and concepts of fairness, though these are likely to be contested. Oversight can include mechanisms of upwards accountability to a hierarchically superior actor, horizontal accountability to peers (eg, peer review mechanisms, including independent verification of, for example, compliance audits, statements of auditors ${ }^{100}$ or appointed actuaries), and downwards accountability to end users, consumers, the polity more broadly. Redress requires that there are avenues for complaint, and for compensatory action should harm result from the actor's decisions or actions.

One of the key concerns with respect to the enrolment of actors is that those actors are only directly accountable to a narrow set of constituents, to the extent they are accountable at all. For example, they are accountable only to members in the case of trade associations, recognised exchanges ${ }^{101}$ and some professional bodies, to shareholders in the case of directors and (theoretically) auditors, to clients in the case of advisors. Attempts may, and have, been

\footnotetext{
99 For discussion of the models see ibid.

$100 \mathrm{Eg}$, in the US the SEC's proposals have to have independent verification of audits: SEC, Commission Formally Proposes Framework of Public Accounting Board, (Washington DC, June 2002), press release available at http://www.sec.gov/news/press/2002-91.htm.

101 The recognition requirements for investment exchanges do not contain any provisions as to board membership, though they do require that the exchange consults prior to issuing rules: Financial Services and Markets Act 2000 (Recognition Requirements for Investment Exchanges and Clearing Houses) Regulations 2001 (SI 2001/995).
} 
made to enhance the accountability of such actors through expanding participation in various ways. This might be through the design of institutional structures. One example is to use institutional structures to enhance accountability to previously identified constituents, eg, corporate governance initiatives aimed at enhancing directors' accountability to shareholders. A second is to adopt a broader, what might be termed 'representative' mode of accountability by requiring that a person or body be appointed to represent other constituents, or ensure that their interests are taken into account in decision-making, eg, the proposals for the appointment of a 'policyholders advocate' on the attribution or re-attribution of orphan assets of life companies, and for the appointment of a policyholders' committee in firms operating withprofits funds). ${ }^{102}$ A third example is to use institutional structures to adopt a 'directly participative' mode of accountability, that is to extend accountability by incorporating a wider set of constituents in key decision-making structures, as in the case of the recently created Accountancy Foundation. ${ }^{103}$ An alternative, or an addition, to changing institutional structures is to change processes: for example, to introduce consultative processes or expand them beyond a narrow range of constituents, and/or to provide for notice and hearings in disciplinary matters.

Which form of accountability each actor should be subject to should vary with the role that they play within the regulatory system, both in terms of the regulatory function that they exercise, and in terms of the extent to which they are enrolled. Moreover, different combinations of the two options outlined above, derivative or 'chain' accountability and direct accountability, will be appropriate in different regulatory systems. Accountability issues are not simple to resolve, but it is essential that discussions of the accountability of any one regulatory system recognise that in decentralised systems of regulation, characterised by fragmentation, hybridisation and patterns of enrolment, models of accountability which are centred on state actors will be inevitably partial and inadequate.

\section{Conclusions}

An enrolment perspective undoubtedly results in a complex map of the regulatory system, but it is one which arguably enables better navigation through the system itself, and through the questions of how it should develop. It requires attention to be paid to the way that regulation happens on the ground and to the relationships between actors that are created, and not simply to the statutory provisions or formal regulatory rules. By focusing on actors, capacities and interrelationships, it forces the categorisations of 'state' or 'self'-regulation to be broken down, and a more fine-grained analysis of the regulatory capacities actors to be formulated. Finally, it facilitates a discussion of the accountability of the system which recognises that systems of accountability have to be as multiple and fragmented as the system of regulation itself.

\footnotetext{
102 FSA (2002), Feedback Statement on the With Profits Review (London, May 2002).

103 For details see Accountancy Foundation, Independent Review of the Accountancy Profession (London, January 2002), available at http://www.accountancyfoundation.com.
} 
Appendix 1: Differential regulatory capacities: preliminary assessment of capacities of potential actors

\begin{tabular}{|c|c|c|c|c|c|c|c|c|c|}
\hline Capacity & Resources & & & & & & Context & & \\
\hline Actors & Information & Expertise & Financial & $\begin{array}{l}\text { Authority / } \\
\text { legitimacy }\end{array}$ & $\begin{array}{l}\text { Strategic } \\
\text { position }\end{array}$ & $\begin{array}{l}\text { Organisational } \\
\text { capacity }\end{array}$ & Legal context & $\begin{array}{l}\text { Market and } \\
\text { economic } \\
\text { context }\end{array}$ & $\begin{array}{l}\text { Political and } \\
\text { social context }\end{array}$ \\
\hline $\begin{array}{l}\text { International } \\
\text { financial } \\
\text { institutions (eg, } \\
\text { World Bank, } \\
\text { IMF) }\end{array}$ & $\begin{array}{l}\text { Reliance on } \\
\text { provision by } \\
\text { countries/ } \\
\text { experts, but } \\
\text { existing } \\
\text { systems in } \\
\text { place for } \\
\text { collection for } \\
\text { monitoring } \\
\text { (ROSCs, } \\
\text { FSAPs) }\end{array}$ & $\begin{array}{l}\text { Strong in } \\
\text { traditional } \\
\text { areas; weak as } \\
\text { move beyond } \\
\text { them (eg, WB } \\
\text { and IMF low } \\
\text { in expertise on } \\
\text { insurance, } \\
\text { securities, CG, } \\
\text { governance, } \\
\text { auditing, } \\
\text { accounting, } \\
\text { insolvency) }\end{array}$ & $\begin{array}{l}\text { Funding base } \\
\text { of institution } \\
\text { secure; } \\
\text { management } \\
\text { decision as to } \\
\text { commitment } \\
\text { of resources to } \\
\text { area }\end{array}$ & $\begin{array}{l}\text { International legal } \\
\text { mandates } \\
\text { Membership and } \\
\text { decision-making } \\
\text { have high degree } \\
\text { of } \\
\text { representativeness, } \\
\text { transparency of } \\
\text { processes } \\
\text { increasing }\end{array}$ & $\begin{array}{l}\text { Cross- } \\
\text { jurisdictional } \\
\text { Occupy key } \\
\text { strategic } \\
\text { position vis-à- } \\
\text { vis countries } \\
\text { needing } \\
\text { financial } \\
\text { assistance } \\
\text { Political } \\
\text { resource for } \\
\text { national } \\
\text { regulators }\end{array}$ & $\begin{array}{l}\text { Large } \\
\text { secretariats, } \\
\text { existing systems } \\
\text { in place for } \\
\text { monitoring and } \\
\text { assessments }\end{array}$ & $\begin{array}{l}\text { Subject to } \\
\text { legally defined } \\
\text { jurisdictional, } \\
\text { substantive and } \\
\text { procedural } \\
\text { limitations }\end{array}$ & $\begin{array}{l}\text { Ability to } \\
\text { deploy } \\
\text { strategic } \\
\text { position } \\
\text { varies with } \\
\text { financial state } \\
\text { of country }\end{array}$ & $\begin{array}{l}\text { Relatively } \\
\text { insulated from } \\
\text { pressures and } \\
\text { interests of } \\
\text { national } \\
\text { politics } \\
\text { May be } \\
\text { political } \\
\text { sensitivities to } \\
\text { appropriateness } \\
\text { of actions and } \\
\text { recognition of } \\
\text { legitimacy in } \\
\text { particular areas }\end{array}$ \\
\hline $\begin{array}{l}\text { International } \\
\text { government } \\
\text { groupings and } \\
\text { standard-setting } \\
\text { bodies (eg G7, } \\
\text { G10, G22, } \\
\text { BCBS, IOSCO, } \\
\text { IAIS, FSF, } \\
\text { FATF) }\end{array}$ & $\begin{array}{l}\text { Possession of } \\
\text { eg, } \\
\text { macroeconomic } \\
\text { information; } \\
\text { reliance on } \\
\text { provision by } \\
\text { countries/ } \\
\text { experts for } \\
\text { other; reliance } \\
\text { on others for } \\
\text { information on } \\
\text { implementation }\end{array}$ & $\begin{array}{l}\text { Specialist } \\
\text { committees } \\
\text { have high } \\
\text { level of } \\
\text { expertise in } \\
\text { respective } \\
\text { areas }\end{array}$ & $\begin{array}{l}\text { May not have } \\
\text { independent } \\
\text { resources; } \\
\text { small and/or } \\
\text { shared } \\
\text { secretariats }\end{array}$ & $\begin{array}{l}\text { No formal legal } \\
\text { mandates } \\
\text { Authority and } \\
\text { legitimacy } \\
\text { dependent on } \\
\text { representativeness } \\
\text { of membership, } \\
\text { procedures, } \\
\text { transparency and } \\
\text { expertise }\end{array}$ & $\begin{array}{l}\text { Cross- } \\
\text { jurisdictional } \\
\text { Bestowal or } \\
\text { withdrawal of } \\
\text { peer esteem } \\
\text { Political } \\
\text { resource for } \\
\text { national } \\
\text { regulators }\end{array}$ & $\begin{array}{l}\text { Variable } \\
\text { May have no } \\
\text { secretariat, small } \\
\text { secretariat or } \\
\text { may be shared } \\
\text { Consultation } \\
\text { and monitoring } \\
\text { practices } \\
\text { variable }\end{array}$ & $\begin{array}{l}\text { No legal } \\
\text { mandate } \\
\text { Any standards } \\
\text { the status of } \\
\text { 'soft law' and } \\
\text { may require } \\
\text { support of legal } \\
\text { environment } \\
\text { for adoption } \\
\text { May be counter } \\
\text { to legal } \\
\text { requirements in } \\
\text { various } \\
\text { jurisdictions }\end{array}$ & $\begin{array}{l}\text { May affect } \\
\text { willingness to } \\
\text { propose } \\
\text { certain } \\
\text { measures }\end{array}$ & $\begin{array}{l}\text { Relatively } \\
\text { insulated from } \\
\text { pressures and } \\
\text { interests of } \\
\text { national } \\
\text { politics } \\
\text { May be } \\
\text { political } \\
\text { sensitivities to } \\
\text { endowment } \\
\text { with formal } \\
\text { authority }\end{array}$ \\
\hline
\end{tabular}




\begin{tabular}{|c|c|c|c|c|c|c|c|c|c|}
\hline Capacity & Resources & & & & & & Context & & \\
\hline Actors & Information & Expertise & Financial & $\begin{array}{l}\text { Authority / } \\
\text { legitimacy }\end{array}$ & $\begin{array}{l}\text { Strategic } \\
\text { position }\end{array}$ & $\begin{array}{l}\text { Organisational } \\
\text { capacity }\end{array}$ & Legal context & $\begin{array}{l}\text { Market and } \\
\text { economic } \\
\text { context }\end{array}$ & $\begin{array}{l}\text { Political and } \\
\text { social context }\end{array}$ \\
\hline $\begin{array}{l}\text { International } \\
\text { standard-setting } \\
\text { Bodies (non- } \\
\text { government } \\
\text { membership: } \\
\text { eg, IASC, } \\
\text { ISMA) }\end{array}$ & $\begin{array}{l}\text { Information on } \\
\text { existing } \\
\text { practices high; } \\
\text { reliance on } \\
\text { others for } \\
\text { information on } \\
\text { implementation }\end{array}$ & $\begin{array}{l}\text { High expertise } \\
\text { in respective } \\
\text { areas }\end{array}$ & $\begin{array}{l}\text { May not be } \\
\text { sufficient to } \\
\text { engage in } \\
\text { systematic } \\
\text { information- } \\
\text { gathering } \\
\text { exercises }\end{array}$ & $\begin{array}{l}\text { No formal legal } \\
\text { mandates } \\
\text { Authority and } \\
\text { legitimacy may be } \\
\text { based on } \\
\text { membership, } \\
\text { procedures, } \\
\text { transparency and } \\
\text { expertise }\end{array}$ & $\begin{array}{l}\text { Cross- } \\
\text { jurisdictional } \\
\text { Own strategic } \\
\text { positions often } \\
\text { weak; rely on } \\
\text { enrolment of } \\
\text { other strategic } \\
\text { actors }\end{array}$ & $\begin{array}{l}\text { Variable } \\
\text { May have no } \\
\text { secretariat, small } \\
\text { secretariat or } \\
\text { may be shared } \\
\text { Consultation } \\
\text { and monitoring } \\
\text { practices } \\
\text { variable }\end{array}$ & $\begin{array}{l}\text { No legal } \\
\text { mandate } \\
\text { Any standards } \\
\text { the status of } \\
\text { 'soft law' and } \\
\text { may require } \\
\text { support of legal } \\
\text { environments } \\
\text { for adoption of } \\
\text { standards } \\
\text { May be counter } \\
\text { to legal } \\
\text { requirements in } \\
\text { various } \\
\text { jurisdictions }\end{array}$ & $\begin{array}{l}\text { May affect } \\
\text { willingness to } \\
\text { propose } \\
\text { certain } \\
\text { measures }\end{array}$ & $\begin{array}{l}\text { Relatively } \\
\text { insulated from } \\
\text { pressures and } \\
\text { interests of } \\
\text { national } \\
\text { politics } \\
\text { May be } \\
\text { political } \\
\text { sensitivities to } \\
\text { endowment } \\
\text { with formal } \\
\text { authority }\end{array}$ \\
\hline $\begin{array}{l}\text { EU institutions } \\
\text { (including } \\
\text { committees, } \\
\text { excluding } \\
\text { courts) }\end{array}$ & $\begin{array}{l}\text { Reliance on } \\
\text { provision by } \\
\text { countries/firms } \\
\text { and experts. } \\
\text { May build own } \\
\text { through } \\
\text { monitoring } \\
\text { initiatives (eg, } \\
\text { post } \\
\text { Lamfalussy } \\
\text { Report 2001) }\end{array}$ & $\begin{array}{l}\text { 'Home- } \\
\text { grown' } \\
\text { expertise of } \\
\text { principal } \\
\text { institutions } \\
\text { limited; reliant } \\
\text { on external } \\
\text { advisors and } \\
\text { technical } \\
\text { committees }\end{array}$ & $\begin{array}{l}\text { Resources } \\
\text { committed to } \\
\text { any area } \\
\text { dependent on } \\
\text { budgetary } \\
\text { policies and } \\
\text { broad resource } \\
\text { constraints } \\
\text { Note } \\
\text { criticisms of } \\
\text { insufficient } \\
\text { resources to } \\
\text { FS issues } \\
\text { (Lamfalussy } \\
\text { Report 2001) }\end{array}$ & $\begin{array}{l}\text { Legal mandate } \\
\text { 'Democratic } \\
\text { deficit' concerns } \\
\text { particularly re: } \\
\text { role of committees }\end{array}$ & $\begin{array}{l}\text { Cross- } \\
\text { jurisdictional } \\
\text { (EU member } \\
\text { states) } \\
\text { May set } \\
\text { conditions for } \\
\text { market access } \\
\text { Could be a } \\
\text { political } \\
\text { resource for } \\
\text { national } \\
\text { regulators }\end{array}$ & $\begin{array}{l}\text { Legislative } \\
\text { process rigid } \\
\text { and } \\
\text { cumbersome } \\
\text { Inter- } \\
\text { institutional } \\
\text { dynamics and } \\
\text { division of } \\
\text { competences } \\
\text { may have } \\
\text { significant } \\
\text { impact }\end{array}$ & $\begin{array}{l}\text { Subject to } \\
\text { legally defined } \\
\text { jurisdictional, } \\
\text { substantive and } \\
\text { procedural } \\
\text { limitations }\end{array}$ & 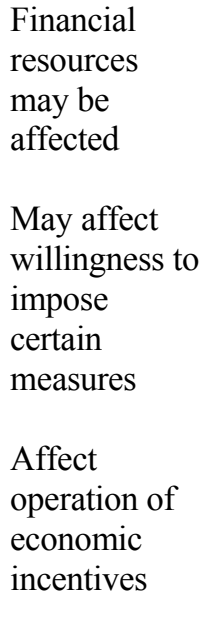 & $\begin{array}{l}\text { Relatively } \\
\text { insulated from } \\
\text { pressures and } \\
\text { interests of } \\
\text { national } \\
\text { politics } \\
\text { May be } \\
\text { political } \\
\text { sensitivities to } \\
\text { legitimacy and } \\
\text { authority of } \\
\text { organisation/ } \\
\text { particular } \\
\text { initiatives }\end{array}$ \\
\hline
\end{tabular}




\begin{tabular}{|c|c|c|c|c|c|c|c|c|c|}
\hline Capacity & Resources & & & & & & Context & & \\
\hline Actors & Information & Expertise & Financial & $\begin{array}{l}\text { Authority / } \\
\text { legitimacy }\end{array}$ & $\begin{array}{l}\text { Strategic } \\
\text { position }\end{array}$ & $\begin{array}{l}\text { Organisational } \\
\text { capacity }\end{array}$ & Legal context & $\begin{array}{l}\text { Market and } \\
\text { economic } \\
\text { context }\end{array}$ & $\begin{array}{l}\text { Political and } \\
\text { social context }\end{array}$ \\
\hline $\begin{array}{l}\text { National } \\
\text { regulators/ } \\
\text { departments }\end{array}$ & $\begin{array}{l}\text { Reliance on } \\
\text { provision by } \\
\text { countries/firms } \\
\text { and experts } \\
\text { May build own } \\
\text { through } \\
\text { monitoring }\end{array}$ & $\begin{array}{l}\text { May be } \\
\text { variable } \\
\text { within and } \\
\text { between } \\
\text { sectors } \\
\text { Sectoral } \\
\text { regulators may } \\
\text { develop } \\
\text { expertise } \\
\text { dependent on } \\
\text { staffing } \\
\text { practices }\end{array}$ & $\begin{array}{l}\text { May have } \\
\text { significant } \\
\text { resource } \\
\text { constraints } \\
\text { depending on } \\
\text { funding } \\
\text { mechanism }\end{array}$ & Legal mandate & $\begin{array}{l}\text { May control } \\
\text { market access } \\
\text { Could be } \\
\text { political } \\
\text { resource for } \\
\text { internal firm } \\
\text { regulators }\end{array}$ & $\begin{array}{l}\text { Responsiveness } \\
\text { of procedures } \\
\text { likely to be } \\
\text { variable } \\
\text { May be issues of } \\
\text { co-ordination, } \\
\text { co-operation and } \\
\text { competition } \\
\text { between } \\
\text { regulatory or } \\
\text { departmental } \\
\text { bodies }\end{array}$ & $\begin{array}{l}\text { Subject to } \\
\text { legally defined } \\
\text { jurisdictional, } \\
\text { substantive and } \\
\text { procedural } \\
\text { limitations }\end{array}$ & 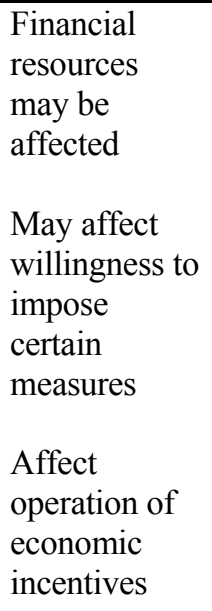 & $\begin{array}{l}\text { Pressures and } \\
\text { interests of } \\
\text { national } \\
\text { politics may be } \\
\text { significant } \\
\text { May be } \\
\text { political } \\
\text { sensitivities to } \\
\text { legitimacy and } \\
\text { authority of } \\
\text { organisation/ } \\
\text { particular } \\
\text { initiative }\end{array}$ \\
\hline $\begin{array}{l}\text { National and } \\
\text { international } \\
\text { commercially- } \\
\text { based } \\
\text { organisations, } \\
\text { including } \\
\text { market } \\
\text { organisers, } \\
\text { epistemic and } \\
\text { interest groups }\end{array}$ & $\begin{array}{l}\text { High levels of } \\
\text { specialist } \\
\text { information }\end{array}$ & $\begin{array}{l}\text { High expertise } \\
\text { in respective } \\
\text { areas }\end{array}$ & $\begin{array}{l}\text { Formal } \\
\text { organisations } \\
\text { funded by } \\
\text { members }\end{array}$ & $\begin{array}{l}\text { May or may not } \\
\text { have legal } \\
\text { mandate or be } \\
\text { integrated into } \\
\text { legal system of } \\
\text { regulation } \\
\text { Authority and } \\
\text { legitimacy related } \\
\text { to membership, } \\
\text { procedures and } \\
\text { expertise }\end{array}$ & $\begin{array}{l}\text { Bestowal or } \\
\text { withdrawal of } \\
\text { peer esteem } \\
\text { May control } \\
\text { market access }\end{array}$ & $\begin{array}{l}\text { Variable } \\
\text { May be issues of } \\
\text { co-ordination, } \\
\text { co-operation or } \\
\text { competition } \\
\text { between } \\
\text { organisations }\end{array}$ & $\begin{array}{l}\text { May require } \\
\text { support of legal } \\
\text { environments } \\
\text { for adoption of } \\
\text { standards }\end{array}$ & $\begin{array}{l}\text { Funding may } \\
\text { be affected } \\
\text { May affect } \\
\text { perceived } \\
\text { capacity to } \\
\text { impose } \\
\text { certain } \\
\text { standards or } \\
\text { take certain } \\
\text { enforcement } \\
\text { actions }\end{array}$ & $\begin{array}{l}\text { May be } \\
\text { political } \\
\text { sensitivities to } \\
\text { legitimacy and } \\
\text { authority of } \\
\text { organisation/ } \\
\text { particular } \\
\text { initiative and to } \\
\text { endowment } \\
\text { with formal } \\
\text { authority }\end{array}$ \\
\hline
\end{tabular}




\begin{tabular}{|c|c|c|c|c|c|c|c|c|c|}
\hline Capacity & Resources & & & & & & Context & & \\
\hline Actors & Information & Expertise & Financial & $\begin{array}{l}\text { Authority / } \\
\text { legitimacy }\end{array}$ & $\begin{array}{l}\text { Strategic } \\
\text { position }\end{array}$ & $\begin{array}{l}\text { Organisational } \\
\text { capacity }\end{array}$ & Legal context & $\begin{array}{l}\text { Market and } \\
\text { economic } \\
\text { context }\end{array}$ & $\begin{array}{l}\text { Political and } \\
\text { social context }\end{array}$ \\
\hline $\begin{array}{l}\text { National and } \\
\text { international } \\
\text { non- } \\
\text { commercial } \\
\text { actors } \\
\text { (eg, consumer } \\
\text { bodies, NGOs, } \\
\text { charities) }\end{array}$ & $\begin{array}{l}\text { Variable; may } \\
\text { conduct own } \\
\text { research and } \\
\text { monitoring } \\
\text { (dependent on } \\
\text { resources) } \\
\text { Information } \\
\text { possessed may } \\
\text { be fragmented }\end{array}$ & $\begin{array}{l}\text { Variable, often } \\
\text { low }\end{array}$ & $\begin{array}{l}\text { Often low } \\
\text { financial } \\
\text { resources }\end{array}$ & 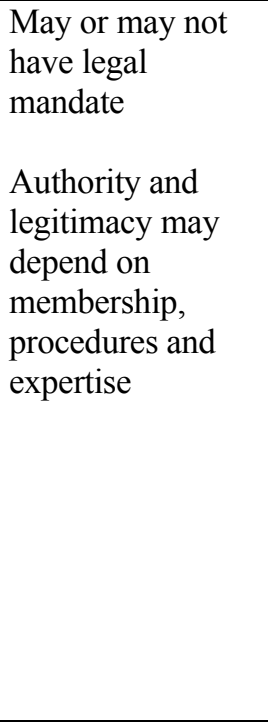 & $\begin{array}{l}\text { Not tied to } \\
\text { national } \\
\text { boundaries } \\
\text { May have } \\
\text { good access to } \\
\text { the media } \\
\text { May be } \\
\text { potential } \\
\text { legitimacy } \\
\text { resource } \\
\text { May be in a } \\
\text { position to } \\
\text { mobilise } \\
\text { consumer } \\
\text { action }\end{array}$ & $\begin{array}{l}\text { Variable } \\
\text { Issues of } \\
\text { co-ordination, } \\
\text { co-operation or } \\
\text { competition } \\
\text { between } \\
\text { organisations }\end{array}$ & $\begin{array}{l}\text { May endow } \\
\text { with legal } \\
\text { authority to } \\
\text { participate in } \\
\text { regulatory } \\
\text { process (eg, } \\
\text { consultations, } \\
\text { enforcement) }\end{array}$ & $\begin{array}{l}\text { May affect } \\
\text { funding }\end{array}$ & $\begin{array}{l}\text { May be } \\
\text { political } \\
\text { sensitivities to } \\
\text { endowment } \\
\text { with formal } \\
\text { authority to } \\
\text { exercise a } \\
\text { particular } \\
\text { control } \\
\text { function }\end{array}$ \\
\hline $\begin{array}{l}\text { Market Actors } \\
\text { - Gatekeepers }\end{array}$ & $\begin{array}{l}\text { Specialist and } \\
\text { fragmented } \\
\text { May or may not } \\
\text { collate } \\
\text { information } \\
\text { across actors }\end{array}$ & Variable & $\begin{array}{l}\text { Dependent on } \\
\text { market } \\
\text { position }\end{array}$ & $\begin{array}{l}\text { May have no legal } \\
\text { mandate } \\
\text { Authority and } \\
\text { legitimacy may } \\
\text { depend on } \\
\text { procedures and } \\
\text { expertise }\end{array}$ & $\begin{array}{l}\text { Occupy } \\
\text { strategic } \\
\text { position by } \\
\text { definition }\end{array}$ & Variable & $\begin{array}{l}\text { Legal context } \\
\text { affect rights to } \\
\text { receive, use } \\
\text { and } \\
\text { disseminate } \\
\text { information; } \\
\text { affect ability to } \\
\text { affect property } \\
\text { rights and } \\
\text { impose } \\
\text { contractual } \\
\text { provisions }\end{array}$ & $\begin{array}{l}\text { If strategic } \\
\text { position } \\
\text { arises from } \\
\text { market } \\
\text { position, will } \\
\text { be dependent } \\
\text { on market } \\
\text { context }\end{array}$ & $\begin{array}{l}\text { May be } \\
\text { political } \\
\text { sensitivities to } \\
\text { endowment } \\
\text { with formal } \\
\text { authority to } \\
\text { exercise a } \\
\text { particular } \\
\text { control } \\
\text { function }\end{array}$ \\
\hline
\end{tabular}




\begin{tabular}{|c|c|c|c|c|c|c|c|c|c|}
\hline Capacity & Resources & & & & & & Context & & \\
\hline Actors & Information & Expertise & Financial & $\begin{array}{l}\text { Authority / } \\
\text { legitimacy }\end{array}$ & $\begin{array}{l}\text { Strategic } \\
\text { position }\end{array}$ & $\begin{array}{l}\text { Organisational } \\
\text { capacity }\end{array}$ & Legal context & $\begin{array}{l}\text { Market and } \\
\text { economic } \\
\text { context }\end{array}$ & $\begin{array}{l}\text { Political and } \\
\text { social context }\end{array}$ \\
\hline - Advisors & $\begin{array}{l}\text { Specialised and } \\
\text { fragmented } \\
\text { May or may not } \\
\text { collate } \\
\text { information } \\
\text { across actors }\end{array}$ & $\begin{array}{l}\text { High expertise } \\
\text { in respective } \\
\text { areas }\end{array}$ & $\begin{array}{l}\text { Dependent on } \\
\text { market } \\
\text { position }\end{array}$ & $\begin{array}{l}\text { No legal mandate } \\
\text { Authority may } \\
\text { depend on } \\
\text { expertise }\end{array}$ & $\begin{array}{l}\text { May occupy } \\
\text { strategic } \\
\text { position and } \\
\text { have } \\
\text { privileged } \\
\text { access to firm }\end{array}$ & Variable & $\begin{array}{l}\text { Legal context } \\
\text { affects terms of } \\
\text { relationship } \\
\text { with clients, } \\
\text { reception, use } \\
\text { and } \\
\text { dissemination } \\
\text { of information }\end{array}$ & $\begin{array}{l}\text { May affect } \\
\text { demand for } \\
\text { services }\end{array}$ & $\begin{array}{l}\text { May be } \\
\text { political } \\
\text { sensitivities to } \\
\text { endowment } \\
\text { with formal } \\
\text { authority to } \\
\text { exercise a } \\
\text { particular } \\
\text { control } \\
\text { function }\end{array}$ \\
\hline $\begin{array}{l}\text { - Competitors } \\
\text { and } \\
\text { professional } \\
\text { counterparties }\end{array}$ & $\begin{array}{l}\text { Fragmented; } \\
\text { access to } \\
\text { information } \\
\text { variable; } \\
\text { dependent on } \\
\text { eg, legal } \\
\text { context and } \\
\text { market power } \\
\text { to extract } \\
\text { information }\end{array}$ & Variable & $\begin{array}{l}\text { Dependent on } \\
\text { market } \\
\text { position }\end{array}$ & No legal mandate & $\begin{array}{l}\text { Variable with } \\
\text { market power }\end{array}$ & Variable & $\begin{array}{l}\text { Legal context } \\
\text { affect rights to } \\
\text { receive, use, } \\
\text { disseminate } \\
\text { information; } \\
\text { affect ability to } \\
\text { affect property } \\
\text { rights and } \\
\text { impose } \\
\text { contractual } \\
\text { provisions }\end{array}$ & $\begin{array}{l}\text { Market } \\
\text { position will } \\
\text { affect ability } \\
\text { to exercise a } \\
\text { control } \\
\text { function }\end{array}$ & $\begin{array}{l}\text { May be } \\
\text { political } \\
\text { sensitivities to } \\
\text { endowment } \\
\text { with formal } \\
\text { authority to } \\
\text { exercise a } \\
\text { particular } \\
\text { control } \\
\text { function }\end{array}$ \\
\hline - Consumers & $\begin{array}{l}\text { Fragmented; } \\
\text { access to } \\
\text { information } \\
\text { variable; } \\
\text { dependent on } \\
\text { eg, legal } \\
\text { context and } \\
\text { market power } \\
\text { to extract } \\
\text { information }\end{array}$ & $\begin{array}{l}\text { Variable, often } \\
\text { low }\end{array}$ & Variable & No legal mandate & $\begin{array}{l}\text { Aggregative } \\
\text { action required }\end{array}$ & $\mathrm{N} / \mathrm{A}$ & $\begin{array}{l}\text { Legal context } \\
\text { affects rights to } \\
\text { receive and use } \\
\text { information; } \\
\text { affects property } \\
\text { rights, } \\
\text { contracting } \\
\text { rights }\end{array}$ & $\begin{array}{l}\text { Market } \\
\text { context may } \\
\text { affect } \\
\text { individual } \\
\text { ability to } \\
\text { exercise } \\
\text { control } \\
\text { function }\end{array}$ & $\begin{array}{l}\text { May affect } \\
\text { primacy of } \\
\text { 'caveat } \\
\text { emptor' } \\
\text { principle }\end{array}$ \\
\hline
\end{tabular}




\begin{tabular}{|c|c|c|c|c|c|c|c|c|c|}
\hline Capacity & Resources & & & & & & Context & & \\
\hline Actors & Information & Expertise & Financial & $\begin{array}{l}\text { Authority / } \\
\text { legitimacy }\end{array}$ & $\begin{array}{l}\text { Strategic } \\
\text { position }\end{array}$ & $\begin{array}{l}\text { Organisational } \\
\text { capacity }\end{array}$ & Legal context & $\begin{array}{l}\text { Market and } \\
\text { economic } \\
\text { context }\end{array}$ & $\begin{array}{l}\text { Political and } \\
\text { social context }\end{array}$ \\
\hline Regulated firm & $\begin{array}{l}\text { Information on } \\
\text { own practices } \\
\text { dependent on } \\
\text { state of } \\
\text { information } \\
\text { flows in firm }\end{array}$ & $\begin{array}{l}\text { Variable, } \\
\text { depending on } \\
\text { factors } \\
\text { including } \\
\text { whether new } \\
\text { business area/ } \\
\text { practice }\end{array}$ & $\begin{array}{l}\text { Dependent on } \\
\text { size and } \\
\text { market } \\
\text { position }\end{array}$ & $\begin{array}{l}\text { Internally: } \\
\text { authority of } \\
\text { management may } \\
\text { vary; authority } \\
\text { and legitimacy of } \\
\text { compliance/other } \\
\text { regulatory } \\
\text { divisions may be } \\
\text { low } \\
\text { Externally: may } \\
\text { be recognised } \\
\text { 'beacon' firm }\end{array}$ & $\begin{array}{l}\text { Overall } \\
\text { management } \\
\text { control of } \\
\text { personnel } \\
\text { through } \\
\text { incentive } \\
\text { structures } \\
\text { Internallly: } \\
\text { 'regulators' } \\
\text { may or may } \\
\text { not occupy } \\
\text { strategic } \\
\text { positions } \\
\text { Externally: } \\
\text { variable with } \\
\text { market power/ } \\
\text { recognition as } \\
\text { 'beacon' firm }\end{array}$ & Variable & $\begin{array}{l}\text { Internally: } \\
\text { employment } \\
\text { law affects } \\
\text { terms of } \\
\text { relationships } \\
\text { with } \\
\text { employees; } \\
\text { company law } \\
\text { affects duties } \\
\text { of directors; } \\
\text { whistleblower } \\
\text { protection } \\
\text { Externally: } \\
\text { constraints } \\
\text { imposed in } \\
\text { private law }\end{array}$ & $\begin{array}{l}\text { May affect } \\
\text { organisational } \\
\text { capacity } \\
\text { Market } \\
\text { position will } \\
\text { affect ability } \\
\text { to exercise } \\
\text { control } \\
\text { functions } \\
\text { over other } \\
\text { firms }\end{array}$ & $\begin{array}{l}\text { May be } \\
\text { political } \\
\text { sensitivities to } \\
\text { endowment } \\
\text { with formal } \\
\text { authority to } \\
\text { exercise a } \\
\text { particular } \\
\text { control } \\
\text { function }\end{array}$ \\
\hline
\end{tabular}


- Perceptions of Risk: an experimental approach using internet questionnaires Frank A. Cowell and Guillermo Cruces

DP 18
- Reforming the UK Flood Insurance Regime. The Breakdown of a Gentlemen's Agreement Michael Huber

DP 19

\section{Available now in print or from http://www.lse.ac.uk/collections/CARR/documents/Default.htm}

- Mapping the Contours of

Contemporary Financial Services

Regulation

Julia Black

DP 17

- The Invention of Operational Risk

Michael Power

DP 16

- Precautionary Bans or Sacrificial Lambs? Participative Risk Regulation and the Reform of the UK Food Safety Regime

Henry Rothstein

- Incentives, Choice and Accountability in the Provision of Public Services Timothy Besley and Maitreesh Ghatak

- Regulating Parliament: the regulatory state within Westminster

Robert Kaye

DP 13

- Business History and Risk

Terry Gourvish

Business Risk and Antitrust:

comparative perspectives

Tony Freyer

The Risks of Working and the Risks of Not Working: historical perspectives on employers, workers, and occupational illness

Joseph Melling

DP 12

- The Open Method of Co-ordination and the European Welfare State Damian Chalmers and Martin Lodge

- Drivers and Drawbacks: regulation and environmental risk management systems

Marius Aalders

DP 10

- Conceptualising Insurance: risk management under conditions of solvency Michael Huber
- Social Licence and Environmental Protection: why businesses go beyond compliance

Neil Gunningham, Robert Kagan and

Dorothy Thorton

DP 8

- Neglected Risk Regulation: the institutional attenuation phenomenon Henry Rothstein

- Mass Media and Political Accountability Tim Besley, Robin Burgess and Andrea Pratt

DP 6

- Embedding Regulatory Autonomy: the reform of Jamaican telecommunications regulation 19882001

Lindsay Stirton and Martin Lodge DP 5

- Critical Reflections on Regulation Julia Black

- The New Politics of Risk Regulation in Europe

David Vogel

DP 3

- The EU Commission and National Governments as Partners: EC regulatory expansion in telecommunications 1979-2000 Mark Thatcher

- Regulating Government in a 'Managerial' Age: towards a crossnational perspective Christopher Hood and Colin Scott DP 1

- Is Regulation Right?

Robert Baldwin

Business Risk Management in Government: pitfalls and possibilities Christopher Hood and Henry Rothstein

Risk Management and Business Regulation Bridget Hutter and Michael Power DP 0 